PUBLICATIONS

\title{
A Workshop on
}

\section{STEEL RESEARCH NEEDS FOR BUILDINGS}
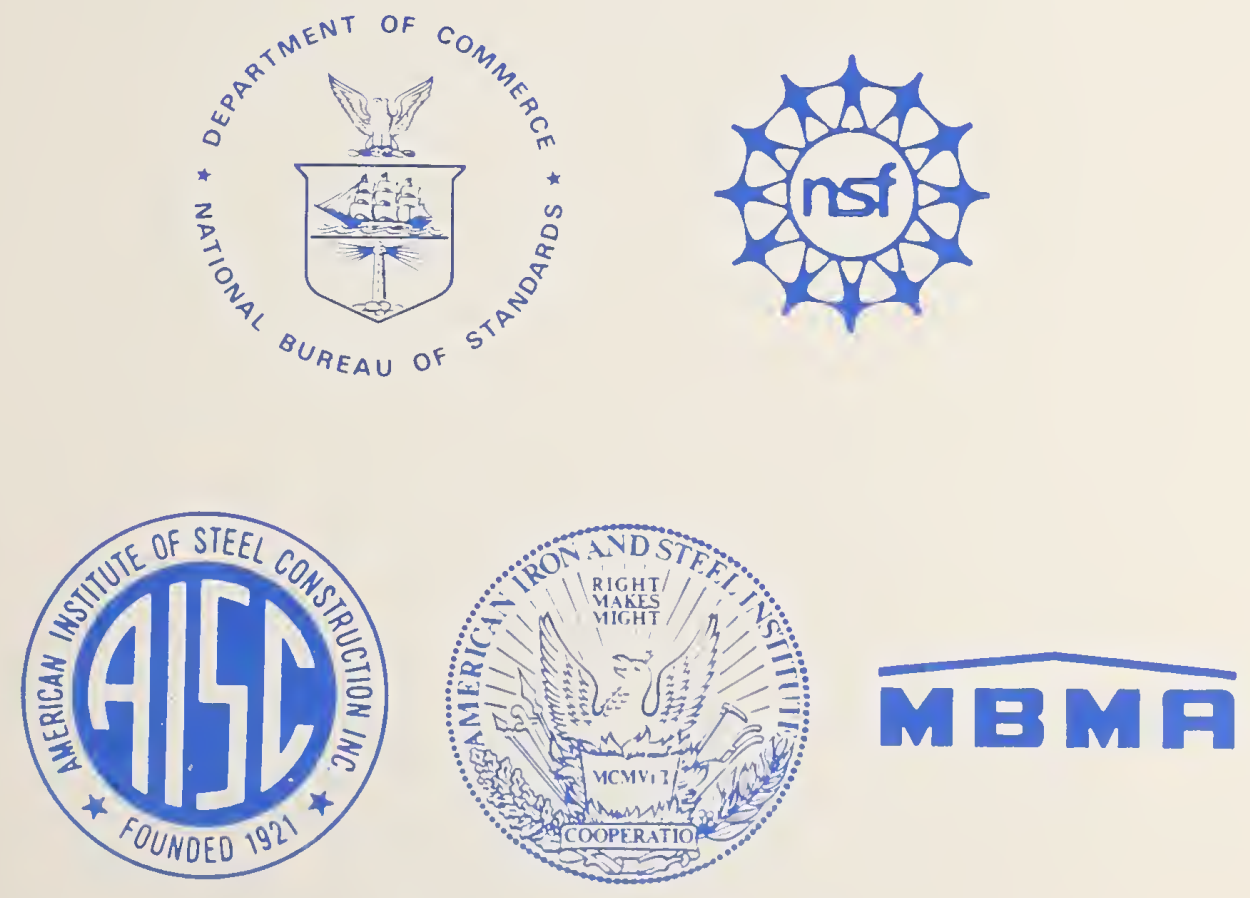
he National Bureau of Standards ${ }^{1}$ was established by an act of Congress on March 3, 1901. The Bureau's overall goal is to strengthen and advance the nation's science and technology and facilitate their effective application for public benefit. To this end, the Bureau conducts research and provides: (1) a basis for the nation's physical measurement system, (2) scientific and technological services for industry and government, (3) a technical basis for equity in trade, and (4) technical services to promote public safety. The Bureau's technical work is performed by the National Measurement Laboratory, the National Engineering Laboratory, the Institute for Computer Sciences and Technology, and the Center for Materials Science.

\section{The National Measurement Laboratory}

Provides the national system of physical and chemical measurement; coordinates the system with measurement systems of other nations and furnishes essential services leading to accurate and uniform physical and chemical measurement throughout the Nation's scientific community, industry, and commerce; provides advisory and research services to other Government agencies; conducts physical and chemical research; develops, produces, and distributes Standard Reference Materials; and provides calibration services. The Laboratory consists of the following centers:
- Basic Standards ${ }^{2}$

- Radiation Research

- Chemical Physics

- Analytical Chemistry

\section{The National Engineering Laboratory}

Provides technology and technical services to the public and private sectors to address national needs and to solve national problems; conducts research in engineering and applied science in support of these efforts; builds and maintains competence in the necessary disciplines required to carry out this research and technical service; develops engineering data and measurement capabilities; provides engineering measurement traceability services; develops test methods and proposes engineering standards and code changes; develops and proposes new engineering practices; and develops and improves mechanisms to transfer results of its research to the ultimate user. The Laboratory consists of the following centers:
- Applicd Mathematic

- Electronics and Ficetricil Engineering ${ }^{2}$

- Manufacturing Engineering

- Building Technology

- Fire Rescarch

- Chemical Enginecring²

\section{The Institute for Computer Sciences and Technology}

Conducts research and provides scientific and technical services to aid Federal agencies in the selection, acquisition, application, and use of computer technology to improve effectiveness and economy in Government operations in accordance with Public Law 89-306 (40 U.S.C. 759), relevant Executive Orders, and other directives; carries out this mission by managing the Federal Information Processing Standards Program, developing Federal ADP standards guidelines, and managing Federal participation in ADP voluntary standardization activities; provides scientific and rechnological advisory services and assistance to Federal agencies; and provides the technical foundation for computer-related policies of the Federal Government. The Institute consists of the following centers:

\section{The Center for Materials Science}

Conducts research and provides measurements, data, standards, reference materials, quantitative understanding and other technical information fundamental to the processing, structure, properties and performance of materials; addresses the scientific basis for new advanced materials technologies; plans research around cross-country scientific themes such as nondestructive evaluation and phase diagram development; oversees Bureau-wide lechnicil programs in nuclear reactor radiation research and nondestructive evaluation; and broadly disseminates generic technical information resulting from its programs. The Center consists of the following Divisions:
- Programming Sicincis and Techmolog!

- Computer Syscems Enginecring
- Inorganic Malcrials

- Fracture and 1):formallom

- Polymers

- Metallurg!

- Reáctor Radiallon 


\section{Steel Research Needs for Buildings}

Proceedings of a Workshop Sponsored By:

National Bureau of Standards

National Science Foundation

American Institute of Steel Construction

American Iron and Steel Institute

Metal Building Manufacturers Association

Held at the National Bureau of Standards

Gaithersburg, Maryland

March 5-6, 1985

Edited by:

Charles Culver

National Bureau of Standards

Nestor Iwankiw

American Institute of Steel Construction

Albert Kuentz

American Iron and Steel Institute

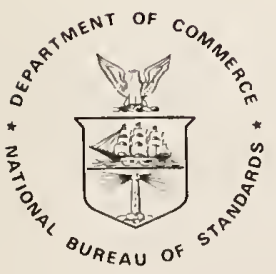

U.S. DEPARTMENT OF COMMERCE, Malcolm Baldrige, Secretary 
U.S. GOVERNMENT PRINTING OFFICE WASHINGTON: 1985 


\section{ABSTRACT}

This report identifies experimental and analytical research needed to advance the state-of-the-art and improve safety and economy in the design, fabrication and construction of steel buildings. A five year plan for a coordinated research program is included. Recommendations for research projects dealing with the following topics are presented: total building systems, connections and members, frames, seismic design, load and resistance factor design, fire protection, and design loads. The recommendations were developed at a workshop involving participation by steel industry representatives, design professionals, Federal agency representatives and university researchers.

Reywords: buildings, design, fire protection, loads, research, steel, structural engineering. 
ABSTRACT • . . . . . . . . . . . . . . . . . . . iii

INTRODUCTION

Background

Steel Industry Building Research . . . . . . . . . . 4

Research Needs Workshop . . . . . . . . . . . 8

Coordinated Research Program . . . . . . . . . . 9

RESEARCH OPPORTUNITIES . . . . . . . . . . . . . . . . 11

A. Total Building System . . . . . . . . . . . 11

Al: On-Site Fabrication . . . . . . . . . 11

A2: Erection Procedures . . . . . . . . . 12

A3: Innovative Systems . . . . . . . . . . 12

A4: Large-Scale Testing ............ 13

B. Connections and Members . . . . . . . . . . 13

Bl: Steel Structures Exposed to Severe

Environments .............. 13

B2: Performance of Connections in Weathering

Steel structures........... . 14

B3: Web Stiffeners . . . . . . . . . . 14

B4: Seated Beam Connections . . . . . . . 15

B5: Semi-Rigid Connections . . . . . . . . 16

B6: Beam-to-Column Connections . . . . . . 16

B7: Load Deformation Behavior of Welds . . . . 17

B8: Moment Connections to Column Webs . . . . 18

B9: Lateral and Local Instability of Beams . . . 18

Bl0: Strength of Webs and Plates Under Fillet weld Groups ............ . 19

Bll: Composite Columns ............ . 19

B12: Composite Floor Systems . . . . . . . 20

B13: Bar Joist Systems ............ 20

B14: New Structural Members . . . . . . . . 21

C. Frames . . . . . . . . . . . . . . 21

Cl: Three Dimensional Behavior . . . . . . . 21

C2: Influence of Connections . . . . . . . 22

C3: Cladding and Infilling . . . . . . . . . 22

C4: Lateral Deflection ............ 23 
C5: Field Measurements ........... 24

C6: Composite Construction .......... . 24

C7: Cold-Formed Construction . . . . . . . 25

C8: Non-Compact Sections .......... 25

D. Seismic Design . . . . . . . . . . 26

Dl: Behavior of Semi-Rigid Connections . . . . 26

D2: Drift Control Criteria . . . . . . . 27

D3: Seismic Performance ............ 28

D4: Steel Stud Walls ............. 28

D5: Beam-Column Joints ............ . 29

D6: Beam-Columns .............. . 30

D7: Tubular Members ........... 31

D8: End-Plate Beam-to-Column Connections . . 32

D9: Bolted Web Moment Connections . . . . . 33

D10: Bracing Connections .......... 34

Dll: Viscoelastic Damping .......... 35

D12: Ductility Demand ............. 36

Dl3: Braced Frame Stability ......... 36

Dl4: Lateral Bracing ............ . 37

D15: Overall System Response ........ . 38

D16: Evaluation of Existing Buildings ..... 39

E. Load and Resistance Factor Design ........ 40

El: Connections With Oversize Holes . . . . 40

E2: Web Crippling .............. 40

E3: Technology Transfer ............4 41

E4: Resistance Factors .............4 41

E5: Serviceability Criteria ........ 42

E6: Lateral Motion Criteria........ 43

E7: Vibration Control for Light Floor Systems 43

E8: Plastic Design ............... 44

E9: System Reliability............444

El0: Wind and Seismic Effects ....... 45

Ell: Existing Buildings ........... 46

F. Fire Protection . . . . . . . . . 4 47

Fl: Fire Resistant Design ......... 47

F2: Design Aids ........... 47

F3: Shop Applied Fire Protection ...... 48

F 4: Large Area/Large Volume Structures ..... 49

F5: Fire Research Review ......... 49

G. Design Loads . . . . . . . . . . 4 49

Gl: Crane Loads ........... 50

G2: Drifted Snow .............. 50

G3: Cladding Behavior .......... 50 
G4: Wind Loads on Low Rise Buildings . . . . 51

G5: Internal Pressure Loading . . . . . . . 51

G6: Building Response to Winds... . . . . . 52

G7: Large Area Roofs . . . . . . . . . . 52

ACKNOKLEDGHENTS . . . . . . . . . . . . 54

APPERICES . . . . . . . . . . . . . 55

Appendix A - Workshop Keynote Session . . . . . 55

Appendix B - Workshop Program . . . . . . . 67

Appendix C - Workshop Participants . . . . . . 71 


\section{INTRODUCTION}

\section{BACKGROUND}

Steel construction is an important segment of the U.S. economy. Approximately 94 percent of the output of the fabricated structural metal industry is consumed by construction markets. Industrial and commercial building construction account for about two-thirds of this output. Over the past decade the fabricated structural steel market has varied from $3.5 \mathrm{mill}$ ion tons per year to almost $6 \mathrm{mill}$ ion tons per year.

Since its formation more than 60 years ago, the American Institute of Steel Construction. Inc. (AISC) has been the U.S. trade association for the structural steel fabrication industry. The Institute has provided information for structural steel engineering and construction such as the much referenced design specification, standard shape properties and design aids, which are published in the AISC Manual, and has provided services in the form of technical seminars and conferences, marketing and research. The latter activity, sponsored at leading universities and laboratories, has contributed the substance that makes the AISC Specification a world-class design standard. The steel industry has continued to provide funds for research programs even throughout the recent recession. The commitment of AISC and its membership to future research is strong. This research will help advance the state-of-the-art of steel design towards a new generation of AISC Specifications, starting with the Load and Resistance Factor Design (LRFD) Specification and, improved design procedures.

Eight editions of the AISC Manual and Specification provide clear historical evidence of the technical work that has been done and the progress achieved. Plastic design, composite construction, and now LRFD are some of the significant advances. Beginning in 1964, AISC began publishing the quarterly ENGINEERING JOURNAL, which contains articles of current interest to practicing designers. This publication provides a convenient outlet for distribution of new design criteria based on recently completed research and it describes in greater detail the developments in steel design practice.

In addition to its Manual and ENGINEERING JOURNAL, AISC also periodically publishes special texts on particular topics. During the past 2 years, two books have been prepared: Detailing for steel construction and Engineering for steel construction which contain updated steel design and detailing practice. Ongoing AISC research has provided important input to these books.

The American Iron and Steel Institute (AISI), incorporated in 1908, is a non-profit association of the iron and steel industry. Its purposes are 1) to collect statistics and other 
information about the industry; 2 ) to engage in investigations and research; 3) to provide a forum for the exchange of information and discussion of problems relating to the industry; and 4) to promote the use of iron and steel. Institute activities embrace research and technology, engineering, collection and dissemination of statistics, public distribution of information about the industry and its products, public affairs, and discussion of industrial relations including health safety, and hygiene. The Institute has members in the United States, Canada and Latin America.

Promotional activities of the Institute include applied research, product publicity, booklets, trade show participation, motion pictures, seminars, and educational programs. Many of these activities are carried out in cooperation with important customer associations such as the American Institute of steel Construction (AISC).

AISI staff engineers work with public agencies and private organizations to promote maximum use of steel mill products in construction. They are responsible for industry activities related to construction codes and regulatory standards, and for research and studies on fire protection of steel in buildings and seismic-resistant design. These activities benefit architects, design engineers, and the public, and have helped introduce new standards for steel construction and the revision of many obsolete code requirements. These changes have broadened the use of conventional steel construction, stimulated the development of new types of cold-formed steel floor, roof, and wall construction, and reduced building and highway costs. In order to carry out this code-related responsibility more effectively, the Institute maintains field offices in cities throughout the United States.

Thirteen Product Promotion Committees within AISI carry on selected research and promotion programs of specific interest to their members who produce a particular product. Committee members include producers of specialty steels such as stainless steel and tool steel, and producers specifically interested in such mill products as hot rolled and cold finished bars, sheet and strip, large diameter line pipe, steel plate, and structural steel.

The Metal Building Manufacturers Association, Inc. (MBMA), organized in 1956 with 13 companies, grew to 35 member $\mathrm{f}$ irms in 1980. As the industry matured, the number of Association members decreased to 27 in 1985, principally due to mergers consumated between member companies. Association members presently maintain 71 manufacturing plants in 25 states, plus additional facilities in Canada, Europe, Australia, South America and the Middle East. Pre-engineered metal building systems are sold through a network of over 8,800 building contractors.

At present, MBMA manufacturers account for well over 508 of the total market for low-rise, non-residential construction. 
Achieving a high in 1983 of 55.18, pre-engineered metal buildings must now be regarded as the "conventional" way to build 1 and 2 story commercial, community, and industrial buildings. Sales of metal building systems by MBMA members, who presently represent approximately $90 \%$ of the pre-engineered market, have topped the billion-dollar mark in five of the past six years. Since a metal building system only accounts for approximately 208 of the total cost of a building project, the 1984 industry sales high of $\$ 1.33$ billion represents about $\$ 6.7$ billion of in-place construction. steel tonnage rose 338 in 1984 to a record high of $1.14 \mathrm{million}$ tons.

In close cooperation with AISC and AISI, MBMA attacks a broad range of problems facing the steel industry. Through various standing committees, MBMA marshalls its forces through research and other activities to develop and support new design standards, improve the provisions of model building codes, develop new construction practices and safety regulations as they apply to the metal building industry, and generally advance the state-of-the-art in the design and construction of steel buildings. The MBMA Committees include the Technical, Construction, Mill Relations, Marketing Communications, Fire Protection and Related Insurance Matters, Public Relations, and Post-Disaster Committees, to name just a few. Although the Technical Committee is charged with the primary responsibility for developing and monitoring the research effort, appropriate interaction between all committees is maintained to ensure that the industry produces a high quality, reliable building while, at the same time, adequate attention is given to the need to safeguard economy.

Recently, MBMA joined with AISI to explore ways to obtain greater acceptance of metal building systems by industrial park developers and the financial community. MBMA is also working to assist the Metal Building Dealers Association (MBDA) and its members in reaching these and other important interests.

One of the primary objectives of the Metal Building Manufacturers Association, Inc., is to collect, analyze, and disseminate information. These data are then offered to member companies, customers, architects, engineers, and students at engineering schools across the country in the most comprehensive manner possible. By sharing and publishing the results of research, MBMA seeks to generally improve the understanding and acceptance of metal building systems. The data collected through research are published in various documents. The METAL BUILDING SYSTEMS MANUAL, which was updated for the third time in 1981 by the Technical Committee, incorporated the codified standards on wind load criteria from the Western Ontario wind tunnel research project. The Technical Committee also published a structural design text book entitled, The Design of Single story Rigid Frames, a Crane Manual for Metal Building Systems, and cooperated with MBDA in the publication of the book entitled, Metal Building Systems. This year will mark the completion of an entirely new publication, Low Rise Building Systems Manual, which is a primer 
on design and construction practices for low-rise, nonresidential construction and reflects the end result of three decades of research by the industry. Many of the provisions contained in the Design Practices section of the Manual are generally applicable to all types of low-rise construction.

\section{STEEL INDOSTRY BUIIDING RESEARCG}

There is a continuing need for steel research related to building construction. The steel industry, through the American Institute of Steel Construction (AISC), the American Iron and Steel Institute (AISI), the Metal Building Manufacturers Association (MBMA) and individual companies, has sponsored research on steel building construction for over 70 years. Currently, the industry is pursuing an aggressive program of collaborative research and development with a variety of organizations.

The AISC research activities have always been well defined and regularly monitored by its Committee on steel structures Research and the engineering staff. Smaller project task groups composed of industry personnel and outside experts also helped to guide research progress. In most cases, university graduate student teams performed the work under the leadership of an experienced faculty investigator. Results of the research are not only documented in a detailed final report, but are also disseminated in useable form to the structural engineering profession through AISC seminars, publications, and specification revisions.

The main thrust of steel research in the 1950's was plastic design. Annual funding in the $\$ 100,000$ to $\$ 200,000$ range was committed by AISC to research in those years, which culminated with the introduction of the AISC specification Part 2 on plastic design, and with several beneficial changes in allowable stress design due to a recognition of steel's ductility.

From the mid-60's to the 70's, the AISC total research funding declined to about $\$ 60,000-\$ 70,000$ per year. In the 1980's, during a very competitive construction market environment, greater resources were again devoted to steel research on the order of $\$ 150,000$ - $\$ 200,000$ per year.

Typically, a single AISC research contractor receives $\$ 20,000$ to $\$ 50,000$ annually, thereby permitting AISC to support 5 to 10 different projects.

Since the heyday of plastic design studies, the last 20 years of AISC research has been primarily focused on connections - their reliability and economy. The members of AISC, including steel fabricators and professional members, recognize that the integrity of steel structures depends, to a large extent, on the performance of connections. High strength bolts, weldments, composite beams, end plate and shear plate connections have been 
included in the AISC research program during recent years.

Considering the number, complexity, and potential scope of the various technical questions posed by engineers, architects, and fabricators, the AISC research budget by itself does not permit much broadly based basic research in structural steel. Most AISC studies are short range and aimed at developing answers to immediate design problems. Interspersed with this necessary reactive work are some developmental projects aimed at innovative concepts or procedures that will improve the design of steel structures. This AISC effort is extended by cooperative sponsorship of larger scale projects with organizations such as the National Science Foundation (NSF), the National Bureau of Standards (NBS) and the Metal Buildings Manufacturers Association (MBMA). Special attention is given to the coordination of AISC research with that of the American Iron and Steel Institute (AISI). The latter organization is making significant contributions towards longer range building research. To maintain technical liaison with related research councils, AISC also supports the work of the Research Council on structural Connections, the structural stability Research council, the Welding Research Council, and the steel structures Painting Council.

The AISI structural steel research program is monitored by the Committee of steel Plate Producers and the Committee of structural steel Producers. The program has been in operation since 1963. The research covers markets which utilize structural steel and steel plate, with special emphasis on heavy construction. To serve the needs of the majority of users, concentration has been on buildings and bridges.

A prime objective of this research in steel utilization is the creation of new or improved design procedures for structural steel and plate. These procedures frequently form the basis of industry specifications and government codes. A secondary objective is the development of data to mitigate unnecessarily stringent provisions in various design specifications.

The program began with a budget of $\$ 250,000$ per year and climbed to $\$ 600,000$ by 1970. Then in the 70's the research funding gradually declined back to the $\$ 250,000$ figure. The $1980^{\prime} \mathrm{s}$ have seen an increase to $\$ 350,000$ to meet new challenges in the building construction market. The program consists of an ongoing series of projects - typically 12 are underway at any time - encompassing analytical studies, physical testing and preparation of design manuals. Some are started and finished the same year. More complicated studies can encompass a four- to six-year period. The program recently marked an important milestone with completion of over 100 individual projects since its inception.

The selection of research projects begins with a recommendation from an Engineering Subcommittee consisting of engineers from AISI member steel companies. The final approval 
is made by consensus of the Committees of structural steel and Steel Plate Producers.

Once a project is approved, a member of the Engineering subcommittee is appointed project supervisor, overseeing a task force that will plan and direct the project from commencement to completion to ensure that its objectives are met. Task force members can include consultants, educators, engineers, scientists government and code officials, and steel industry personnel.

The research is performed primarily by universities, with some done by private research and consulting organizations, and some by steel company research laboratories. Over 20 universities have taken part in the program.

When a project has been completed, the results are widely disseminated. One technique is to hold seminars in key cities to discuss the project findings. Frequently, the full project report is printed in an AISI "Steel Research for Construction" bulletin - 27 have been printed to date - with copies made available in response to requests.

AISI's research over the years on beam, column and frame behavior has resulted in significant improvements to the provisions of various design specifications - increasing both the economy and safety of steel construction. significant research accomplishments include:

\section{Load and Resistance Factor Design}

Studies begun in 1970 resulted in new limit state criteria containing provisions for loads and load-combinations and rules for the proportioning of structural members and connections. Work continues to improve the reliability of the design format.

\section{Type 2 Construction with Wind Moment Connections}

The investigation begun in 1977 demonstrated the viability of the design procedure and led to a better understanding of the effect of connection flexibility on frame stability.

\section{Connections}

Studies on single plate framing connections resulted in publication of guidelines for the design of these economical connections and provided a clear understanding of their ductility and moment rotation capacity.

In addition, the Institute's studies of fire hazards and fire protection have contributed to new regulatory concepts relative to the use of non-combustibles, matching protection requirements to the severity of hazards, and avoidance of imbalance in fire risks. The result is greater fire safety, often at lower building costs. 
The MBMA research activity has culminated in new and improved design specifications introduced from time to time into the AISC and AISI Specifications and the MBMA Design Practices Manual. The current provisions contained in these documents relative to end-plate connection design, web crippling, the design of tapered members, stability and strength of cold-formed purlins and girts, are but a few of the more notable examples. The recent trend in research activity by MBMA is to focus on building "system" behavior as compared to that of individual components. Thus, new specification provisions are presently being prepared with regard to the required strength, stiffness, and bracing requirements for complete roof systems.

In 1976, MBMA assumed a leadership role in developing new wind load criteria for the design of low-rise buildings. During the ensuing period, extensive research has been conducted in the Boundary Layer wind Tunnel Laboratory at the University of Western ontario under the joint sponsorship of MBMA, AISI and the CSICC. This research has culminated in new wind load provisions which have been accepted in the United States and Canada by a number of the appropriate code bodies. Research on wind effects is continuing at the present time.

MBMA research activities are originated and closely monitored by various small task groups or subcommittees composed of industry personnel, outside experts, representatives from AISC and AISI, and staff personnel. Inspite of recent dips in the economy, MBMA's basic commitment to research has been steadfastly maintained through the years and the present level of activity is in the $\$ 100,000-\$ 150,000$ per year range. The number of individual projects vary from year to year. During the current year, for example, six separate projects are underway. Additionally, MBMA awards two fellowships annually to engineering students pursuing a course of study related to steel buildings. The fellowship objective is to encourage creative design investigation of specialized areas relative to fabricated metal building systems.

The MBMA research effort is extended by cooperative efforts with organizations such as AISC, AISI, and hopefully, in the immediate future, NSF. MBMA also supports the research activities of, and maintains technical liaison with, the wind Engineering Research Council, the Structural Stability Research Council, the Welding Research Council, the Research Council on structural Connections and the Building seismic Safety Council.

Although the steel industry is now experiencing difficult economic conditions, its commitment to continued and expanded steel research is evident. With the cooperation and assistance of government and the engineering community, the industry is confident that this effort will lead to new technological advances that will enhance the state-of-the-art of steel design and construction. 


\section{RESEARCH NEEDS MORKSHOP}

Recognizing the importance of steel research and the need for a coordinated, well-planned program, AISC, AISI, MBMA and the National Bureau of Standards (NBS) decided in 1984 to organize a workshop for the purpose of identifying needed research. The AISC Research Committee, the AISI Building Task Force and the NBS Center for Building Technology developed the initial plan for the workshop. Subsequently, a steering committee consisting of design professionals, industry representatives, government representatives and university researchers was established to plan the technical details.

This report constitutes the proceedings of the workshop on Steel Research Needs for Buildings. The workshop objective was to develop recommendations for experimental and analytical research needed to advance the state-of-the-art and improve safety and economy in the design, fabrication and construction of steel buildings. The recommendations are intended for use by government, industry, and the research community in establishing a cooperative program. Research in the following areas is considered:

Total Building system

Connections and Members

Frames

Seismic Design

Load and Resistance Factor Design

Fire Protection

Design Loads

Workshop participants included representatives from the steel industry, design professionals, Federal agency representatives and university researchers.

The opening session of the workshop included presentations by representatives from the office of Science and Technology Policy, the National Bureau of Standards and the steel industry. These presentations are included in Appendix A. They provide a perspective on structural steel usage in buildings, consider cooperative research efforts involving industry and government, and provide background material for the workshop recommendations.

The recommendations were developed in two days of intensive subcommittee meetings and plenary sessions. Draft recommendations developed by the participants prior to the workshop served as a starting point for the subcommittee discussion. Each subcommittee focused on one of the seven research areas covered by the workshop. A plenary session 
following the subcommittee meetings provided all participants with the opportunity to comment on recommendations developed by each subcommittee. This procedure was repeated to achieve consensus among the participants on the final recommendations.

\section{COORDINATED RBSEARCE PROGRAM}

The workshop recommendations provide the basis for a comprehensive program to improve safety and economy in the design, fabrication and construction of steel buildings. Activities in this direction are underway. AISC is planning a special educators session on May 21, 1985 in Chicago prior to its International Engineering Symposium on Structural Steel with the theme, "Opportunities for Structural Steel Research". Industry and government speakers will outline the major problem areas. Approximately 100 faculty from across the country are expected to attend.

The level of effort required for each workshop recommendation is indicated in terms of man years. A precise estimate of the funds required cannot be determined without detailed planning for each project. Costs for test specimens, computer time, laboratory personnel, etc., need to be established. The total program represents a substantial effort. A well planned multi-year effort using results obtained in each phase to plan subsequent work is clearly more cost effective than simultaneous initiation of work on each recommendation. Recognizing this, the workshop steering Commmittee developed the five-year plan given in Table 1 . Recommended funding requirements were established on the basis of the immediacy of the need for the information by the design profession, the ability to achieve synergism between research projects and the opportunity to obtain results as rapidly as possible. It is anticipated that funding would be provided by the private sector and government organizations.

An effective research program requires a coordinated effort. Industry representatives, government representatives, design professionals and researchers should be involved. This can best be achieved by establishing a steering group to provide guidance in establishing required funding levels for the various activities. The goal of the group would be to provide a vehicle for implementing the research results to achieve rapid improvement in the design and construction of steel buildings. This group would meet on a regular basis, monitor progress of the research and update the research needs. Establishing this steering group should be given priority consideration. 
TABLE 1

FIVE YEAR PLAN

Structural Steel Research for Buildings

\begin{tabular}{|c|c|c|c|c|c|}
\hline $\begin{array}{l}\text { Program } \\
\text { Area }\end{array}$ & $\begin{array}{c}\text { Year } \\
1\end{array}$ & $\begin{array}{c}\text { Year } \\
2\end{array}$ & $\begin{array}{c}\text { Year } \\
3\end{array}$ & $\begin{array}{l}\text { Year } \\
4\end{array}$ & $\begin{array}{c}\text { Year } \\
5\end{array}$ \\
\hline $\begin{array}{l}\text { Total Building } \\
\text { System }\end{array}$ & 300 & 300 & 200 & 200 & 200 \\
\hline $\begin{array}{l}\text { Connections and } \\
\text { Members }\end{array}$ & 800 & 1000 & 1000 & 600 & 600 \\
\hline Frames & 700 & 800 & 1000 & 900 & 500 \\
\hline Seismic Design & 700 & 1000 & 1000 & 600 & 300 \\
\hline $\begin{array}{l}\text { Load and Resistance } \\
\text { Factor Design }\end{array}$ & 600 & 800 & 800 & 1000 & 1000 \\
\hline Fire Protection & 300 & 400 & 300 & 200 & 100 \\
\hline Design Loads & 600 & 700 & 700 & 500 & 300 \\
\hline TOTAL & 4000 & 5000 & 5000 & 4000 & 3000 \\
\hline
\end{tabular}


The workshop recommendations provide opportunities for constructing safer and more economical steel buildings. They represent a comprehensive program with emphasis on:

- characterizing the behavior of individual structural components

- establishing the performance of total building systems

- developing improved design procedures and design criteria

They cover the important areas of building design. Synthesis of existing information, experimental work and analytical studies are included.

The individual recommendations should not be considered in isolation. Although they are grouped according to the research areas dealt with at the workshop, other groupings are possible. In addition, many of the recommendations are interrelated. For example, the research on frames and total building systems should draw upon the work on connections and individual members. Similarly, work on load and resistance factor design encompasses both structural elements and systems.

Each recommendation deals with an important problem area. It is assumed they will all be included in a coordinated research program and therefore they are not listed in priority order. The level of effort for each recommendation represents an estimate of the professional manpower required. Detailed research plans for each project are required to establish specific funding requirements.

\section{A. TOTAL BUILDING SYSTEM}

Much of the research in the past has concentrated on the behavior of individual components and subassemblages of portions of building systems. Consideration should be given to the total building system and various aspects of the building process, including fabrication and erection, to achieve economy for steel buildings.

\section{RECOMMENDATION AI: ON-SITE FABRICATION}

STUDIES SHOULD BE CONDUCTED TO EXPLORE THE FEASIBILITY OP ON-SITE PABRICATION OF STRUCTURAL STEEL COMPONENTS.

The construction industry has made considerable progress in 
developing improved techniques for the fabrication and erection of concrete buildings. Similar innovative erection practices should be developed for steel buildings. One possibility includes utilizing mobile fabrication plants set up at the building site to manufacture large units that could not ordinarily be transported.

Needed research includes identification of fabrication activities more economically carried out on-site rather than in a fabrication shop. Possibilities include fabrication of steel plate shear walls and large tilt-up frame assemblies. Constraints imposed by weather conditions, on-site space limitations, etc., should be considered. Costs associated with each possible on-site activity should be established and compared with current fabrication and transportation costs.

A two man-year level of effort is required.

\section{RECOMMENDATION A2: ERECTION PROCEDDRES}

IMPROVIBD COST EFFECTIVE TECHNIQUES SHOULD BE DEVELOPED FOR ERECTING STEEL BOILDINGS.

A research program should be undertaken to develop a coordinated approach to the fabrication and erection of steel buildings. The program should involve a multidisciplinary group composed of designers, detailers, fabricators, and mill and erection engineers. Techniques used on a recently completed 72story building in Toronto, Canada such as the use of oversized elevators and the panelizations of the steel and granite skin can provide background data. Opportunities to minimize field welding and simplify connection details and development of new framing design concepts should be studied.

A two man-year level of effort is required.

\section{RECOMMENDATION A3: INNOVATIVE SYSTEMS}

\section{INNOVATIVE STRUCTORAL FRAMING SYSTEMS SHOOLD} BE DEVELOPED FOR STEEL BOILDINGS.

Development of the tube concept as a more efficient mechanism than traditional moment resistant or braced frames for resisting lateral loads resulted in more economical high rise structures. New structural systems employing innovative concepts that take advantage of the unique attributes of steel elements should be developed.

A task force composed of architects and structural engineers should be established to identify innovative structural framing concepts. Analytical studies of these concepts should be carried 
out and cost comparisons made with traditional framing systems.

A two man-year level of effort is required.

\section{RECOMENDATION A4: LARGE-SCALE TESTING \\ LARGE-SCALE TESTS SHOULD BE CONDOCTED TO ESTABLISH THE PERFORMANCE OP INNOVATIVE STROCTORAL COMPONENTS AND SYSTEMS.}

Innovative systems may employ concepts not amenable to traditional structural analysis. In these cases, experiments are required to evaluate the performance of such systems, identify the 1 imit states and establish adequate levels of safety. Largescale tests will be required to minimize scale effects inherent in testing small-scale laboratory specimens or to determine how the scale effects can be taken into account.

A mechanism should be established for conducting these experiments utilizing existing large-scale structural research facilities throughout the United States.

A multi man-year level of effort is required.

\section{B. CONNECTIONS AND MEMBERS}

From the fabricators' point of view, except for the cost of material, freight, shop drawings, and cutting members to length, all other costs are associated with providing connections. From the erectors' point of view on a high rise building, about 30 to 40 percent of the erectors' cost is in making the connections. Connection design is important in achieving safe structures. Continued research is needed for improved understanding of connection behavior to achieve more economical and safe structures.

\section{RECOMMENDATION B1: STEEL STRUCTURES EXPOSED TO SEVERE ENVIRONAENTS}

\section{RESEARCH IS NEEDED TO DETERMINE THE EFFECTS OF SEVERE ENVIRONMENTS (COLD AND MOISTURE) ON COMMONLY-USED FABRICATION PROCEDURES.}

Commonly used fabrication procedures and steel materials have resulted in several failures in steel structures exposed to low temperatures. These are design, fabrication and construction relatd issues.

Commonly used cutting techniques often result in plate edge conditions that are not suitable for low temperature service. 
Welded details can result in crack-like conditions with backing bars, runoff tabs or flame cut preparations and transitions. High deposition submerged arc weldments can result in low fracture resistance.

Experimental and analytical studies are needed to evaluate the suitability of using current fabrication procedures for exposed building structures with comonly used steel materials (i.e., A36, A572, A588).

A two man-year level of effort is required.

\title{
RECOMMENDATION B2: PERFORMANCE OF CONNECTIONS IN WEATHERING STEEL STRUCTURES
}

\begin{abstract}
DESIGN RECOMENDATIONS NEED TO BE DEVELOPED FOR BOLTED CONNECTIONS IN BARE WEATHERING STEEL STRUCTURES, SUCH AS BUILDINGS OR TOWERS, TO INSURE THAT THE INTEGRITY OP THE CONNECTIONS IS NOT DEGRADED WITH CONTINUED EXPOSURE TO WEATHERING.
\end{abstract}

Guidelines have been developed for bolt spacing and edge distance limitations that appear to be required to prevent severe bowing caused by corrosion between faying surfaces of lapped connection elements. This condition arises because the corrosion resistance of weathering steel within such lapped areas is no better than that of carbon steel.

Tests of connections that have been exposed for significant time periods should be conducted to determine how such weathering has affected strength and ductility. Important variables would include bolt spacing and edge distance, bolt type and installation method, time and conditions of the exposure, type of loading (tension, compression, shear-static or cyclic), etc. Possible repair methods for such joints should also be investigated. Evaluations of improved methods for making such details (washers for self-draining features; coatings or sheets of adhesives or mastics for the lapped areas) should be made.

A two man-year level of effort is required.

\section{RECOMMEIDATION B3: HEB STIFFENERS}

PROCEDURES NEED TO BE DEVELOPED FOR BOTH DESIGN AND DETAILING OF BEARING AND TRANSVERSE WEB STIFFENERS.

Significant research has been completed on the strength of webs subjected to concentrated loads or shear. The design rules in the AISC specification give, with reasonable reliability, the 
strength of unstiffened webs. When stiffeners are required to support the loads or shear, the current methods for detailing stiffeners are difficult to document because little research is available. For example, bearing stiffeners are commonly fitted between the flanges at great expense, but no data are available to support this practice. The bearing stiffeners are sometimes designed to carry all the load in spite of the ability of the web itself to carry a significant portion of the load. The design of the bearing stiffener-web combination as a column is based on rules of thumb for $\mathbb{R}$ factors and the portion of the web acting with the stiffener. When stiffeners are required to improve the shear buckling capacity of a web, they must have enough moment of inertia to prevent the web from buckling at the stiffener location. Rules of thumb or approximate energy solutions are used to develop design rules. No experimental evidence is available to verify the recommendations.

An analytical and experimental program is needed to study the problem of bearing stiffener and transverse stiffener behavior and design for static loading. Different web depththickness ratios should be considered to cover the range of rolled beams and practical plate girders. Specific attention should be given to the effect of the detail at the far end of the stiffener on the stiffener behavior. 'A few full size specimens should be tested to verify the analytical studies.

A two to three man-year level of effort is required.

\section{RECOMHENDATION B4: SEATED BEAM CONNECTIONS}

\section{TABOLATED OLTIMATE STRENGTH DESIGN VALOES ARE NEEDED FOR BOLTED AND TELDED SEATED BEAM CONNECTIONS.}

Seated connections are often used in steel construction as an erection necessity. Although allowable stress values have been tabulated in the AISC manual for many years, there are few recorded tests. The tabulated values are based on a hypothetical static model. Both welded and bolted seated connections are involved. It is thought that the present load tables may be excessively conservative.

Experimental and analytical studies are required to develop an ultimate strength design basis for seated connections. Both welded and bolted connections should be considered and the studies should include both stiffened and unstiffened seats.

A one man-year level of effort is required. 


\section{RECOMMNDATION B5: SEHI-RIGID CONNECTIONS \\ MOMENT-ROTATION AND DUCTILITY CBARACTERISTICS FOR VARIOUS TYPES OF CONNBCTIONS ARE NEEDBD TO PACILITATE TYPE 3 CONSTRUCTION.}

Analytical techniques are now in existence and are being refined via the computer to analyze and design steel frames with flexible connections. However, a major shortcoming that has prevented regular design office use of Type 3 semi-rigid construction has been lack of reliable data on the structural characteristics of flexible connections, namely their momentrotation curves. Detailed published information on the nonlinear moment-rotation performance of the connection is limited and not readily available to the practicing engineer. Thus, only idealized Type 1 ( $r$ igid) and Type 2 (simple) framing have been employed in buildings. More use could be made of simple low cost semi-rigid connections, with full recognition of their stiffness, strength and ductility, if more complete information was available on their moment-rotation characteristics.

Additional tests are needed to determine typical momentrotation curves for a given. type of connection and their sensitivity to the major design variables. This work, if supplemented by extensive computer analyses should provide a solid basis for generalized methods to approximate momentrotation properties for any connection. Flexible flange plate and cap and seat angle connections have been studied to some extent. Continuation of this work is desirable to establish a valid and complete moment-rotation data base for future design application. It is expected that such research would provide the necessary impetus for more efficient and economical steel design by demonstrating a good alternative to the often restrictive and expensive fully rigid frame.

A three man-year level of effort is required.

\section{RECOHMENDATION B6: BEAY-TO-COLOHN CONNECTIONS}

A COMPREHBNSIVE RESEARCH PROGRAM SHOOLD BE UNDERTARBN TO DEVELOP PROBABILITY-BASED DESIGN CRITERIA FOR BEAH-TO-COLUMN CONNECTIONS.

Continued research on connections has led to the development of design procedures for designing frames with partially restrained connections. Parallel to this analytical advancement, a coordinated effort is necessary to collect reliable momentrotation data, and to produce optimal data for the development of probability-based design criteria.

An experimental and analytical research program including the following work should be undertaken: 
- Collection of moment-rotation data for connections and evaluation and development of analytical models (see RECOMMENDATION B5).

- Systematic categorization of all connection types and the classification of all relevant limit states.

- Development of a computerized data bank on all available experimental and analytical research results relating to connections.

- Identification of the gaps in the available data. Modern tests on many types of connections, performed on the basis of statistical methods, are not available (e.g., column bases, anchorages).

- Development and implementation of a plan to obtain the needed data.

- Development of a logical design method for proportioning the beams, connections and the columns.

- Verification test of a full-scale flexibly-joined frame.

- Systems reliability analysis of all connection types to determine the reliability against the limit states.

- Development of design criteria which result in optimal reliabiity and economy.

A multi year level of effort is required.

\title{
RECOMHENDATION B7: LOAD DEFORMATION BEHAVIOR OP WELDS
}

\begin{abstract}
ACCURATE DETERMINATION OP THE LOAD-DEPORMATION BEHAVIOR FOR ALL WELDING PROCESSES, WELD STRENGTHS, AND LOAD CONDITIONS IS NEEDED.
\end{abstract}

Analytical work has been published which substantiates experimental results indicating that transversely loaded fillet welds are stronger than longitudinally loaded welds. In addition, stress concentrations are known to affect weld strength. Current information is based on tests under near optimum conditions using E60 electrodes.

Research should be undertaken to investigate the range of variables which affect weld strength. In particular, strength and ductility should be investigated considering load orientation with respect to weld axis, weld wire strengths, and welding processes. In addition, single-pass versus multipass welds should be studied to determine the effect of the root pass and mixing of base metal with weld metal. Finally, the effects of 
stress concentrations with regard to load orientation should be investigated.

A one to two man-year level of effort is required.

\section{RECOMMENDATION B8: MOMENT CONNECTIONS TO COLUMN WEBS}

\section{DESIGN CRITERIA AND DETAILING PROCEDURES ARE NEEDED FOR MOMENT PRODUCING CONNECTIONS MADE DIRECTLY TO THE COLUMN WEB.}

In cases where end plate connections or other moment producing connections (such as single plate framing connections) are framed into a column web, little is known regarding the effect on the web.

Research should be initiated to determine allowable beam moments for various web and end plate configurations. Determination should also be made as the most economical fabrication method to be used to strengthen the column web if required. The project would require both physical testing and analytical work.

A two man-year level of effort is required.

\section{RECOMMENDATION B9: LATERAL AND LOCAL INSTABILITY OF BEAMS}

\section{THE EFFECT OF SIMULTANEOUS LATERAL AND LOCAL INSTABILITY ON STRENGTH AND DEFORHATION CAPACITY OF BEAMS SHOULD BE STUDIED FOR LRFD.}

The lateral and local instability provisions for beams in the proposed LRFD specification are similar to those in the current allowable stress design (ASD) for compact beams, not those required for beams in plastic design (PD). Which set of provisions to adopt depends on the inelastic deformation capacity to be achieved or required in design.

Research is needed to examine the inelastic behavior of beams with width-to-thickness ratios of flange and web and lateral bracing spacings at the limits specified in ASD and PD. Special factors to consider include:

- High strength steel beams, repeated and reversed loading, etc.

- The range of parameters to be studiea include: $b_{f} / 2 t_{f}, d / t_{w}$ and $l_{b}$ and the values should range between those specified in ASD and PD. 
An experimental program of research should include full-scale testing of continuous beams and single-story frames. The analytical research should include nonlinear, inelastic frame analysis to determine required deformation capacity.

A two to three man-year level of effort is required.

$\begin{array}{ll}\text { RECOMMEDATION B10: } & \text { STRENGTH OF WEBS AND PLATES } \\ \text { UNDER PILLET WELD GROUPS }\end{array}$

DESIGN AID DETAILING PROCEDURBS ARE NEEDED FOR DETERMINING WEB OR PLATE THICKNESS REQUIRED TO MATCH FILLET TELD STRENGTH.

Current practice uses a method which equates fillet throat allowable stress to web or plate allowable shear stress in order to determine the web or plate thickness required to match the fillet weld strength. For shear alone, this method is correct for a directly welded web connection, but is excessively conservative for a connection using web framing angles. However, when connections are subjected to axial as well as transverse loads, the method referred to above is excessively conservative for both types of connections.

Research is needed to determine accurate procedures and criteria for determining the web or plate thickness required to match fillet weld strength. The parameters to be studied include loads ranging from pure shear to pure axial, coped and uncoped beams, length of connections ranging from $5 \mathrm{l} / 2$ in. to 29 $1 / 2$ in. and various clip and angle leg sizes. Testing of full size components is required. An analytical counterpart may also be desirable.

A two man-year level of effort is required.

\section{RECOMMENATION BII: COMPOSITE COLUMNS}

\section{ANALYTICAL AND EXPERIMENTAL STUDIES SBOULD BE CONDUCTED TO DEVELOP IMPROVED DESIGN PROVISIONS FOR COMPOSITE COLUMNS.}

There is a lack of up-to-date information on the strength of composite columns. Existing test data were obtained from laboratory specimens. Design rules included in the LRFD specification are an extension of the structural stability Research Council studies concerned with allowable stress design. These formulas may be unnecessarily conservative especially for eccentrically loaded columns.

Experimental studies should be conducted on full-scale composite columns. The tests should include the following range 
of parameters: eccentricity ratio - 0 to 2 ; slenderness ratio -

30 to 90; steel area - 5 to 20 percent. Analytical models should be developed for predicting the ultimate strength behavior.

A three man-year level of effort is required.

\title{
RECOMMENDATION B12: COMPOSITE FLOOR SYSTEMS
}

\begin{abstract}
A COMPREHENSIVE RESEARCH PROGRAM SHOULD BE UNDERTAREN TO ESTABLISH STRENGTH CRITERIA FOR COMPOSITE BEAMS AND FLOOR SYSTEMS AND THE DEVBLOPMENT OF INNOVATIVE SYSTEMS USING SUCB CONSTRUCTION.
\end{abstract}

Past research has provided the supporting data for the current design provisions of the proposed LRFD specification. These provisions govern the design of beam sections subjected to positive or negative bending. Work is needed to establish the strength of continuous composite beam and floor systems including the effect of connections with partial rigidity and strength. Preliminary work is underway to investigate the moment-rotation behavior and low-cost composite beam-column connections that rely on the floor reinforcing steel to resist the tension force created by the moment.

The research program on composite construction should consider the following: The effects of construction loads and service loads on permanent deflections; models for predicting the deflection behavior of partially composite systems; the behavior of low cost beam-column connections for composite members; the use of post-tensioned concrete slabs and/or steel beams. Applications to braced frames with composite floors and structures with prefabricated composite units should be studied.

A multi year level of effort is required.

\section{RECOMMENDATION B13: BAR JOIST SYSTEMS}

\section{EXPERIMENTS SHOULD BE CONDUCTED TO BSTABLISH SHEAR CAPACITY AND MINIMUM SIDE COVER IN COMPOSITE BAR JOIST SYSTEMS.}

Economies can be obtained in bar joist construction if the floor slab can be made to act compositely with the girder supporting the bar joists by using shear studs on the girder flange. Information is not available on the performance of shear studs in this condition with bar joists supported on the girder flange in the vicinity of the studs.

Pushout tests on stud assemblies and several full-scale girder tests should be conducted to establish stud capacities and 
side cover requirements for the studs.

A one-half man-year level of effort is required.

\section{RECOMMENDATION BI4: NEW STRUCTURAL MEHBERS}

NEN STRUCTURAL SHAPES SHOULD BE DEVELOPED FOR

IMPROVING THE BCONOMY OF STEEL FRAME BUILDINGS.

The use of large built-up structural members for framing systems is increasing. Economies could be achieved if larger rolled sections with higher moments of inertia were available.

Studies should be conducted to determine the feasibility of producing larger rolled structural shapes, identify the potential market for these shapes and evaluate the savings in fabrication costs.

A one-man year level of effort is required.

\section{PRAMES}

Considerable research has been carried out on the behavior of individual structural elements and on plane frames of small to moderate size. There is also a large body of information available on the behavior of connections, floor systems, partitions, and cladding - elements that affect the loading on frames and their resistance. As indicated by recommendations in other sections of this report, much additional research is needed on all of these elements. But there is a primary need for research directed towards correlating and integrating these influences. Improved understanding of the three dimensional behavior of total building systems involving more realistic assessment of strength, stability, and stiffness is required to reduce costs of steel buildings. The recommendations of this section are intended in various ways to support the attainment of this basic objective.

\section{RECOMMENDATION Cl: THREE DIMENSIONAL BEHAVIOR}

\section{ANALYTICAL AND BXPERIMENTAL STUDIES SHOULD BE CONDUCTED ON THE THREE DIMENSIONAL BEHAVIOR OF STEBL PRAMES.}

The response of bare steel frames to given loads has been, and will probably remain, the basis for the development of design equations. This response - the stiffness and strength of the bare frame - is affected by a number of things: imperfections, residual stresses, material nonlinearities, loading history, large deflections, post-buckling strength, and connection 
behavior.

Analytical and experimental studies are needed to improve the presently inadequate level of understanding of bare frame behavior. Realistic analytical modeling of three dimensional frames that includes these effects is needed. Parallel laboratory testing of three dimensional subassemblages and small buildings should be conducted to provide information needed to calibrate or to confirm these models. The physical research should be on multistory frames - of the order of three to eight stories - and should include both service load and ultimate load behavior.

A multi man-year level of effort is required.

\title{
RECOMLENDATION C2: INFLUENCE OF CONNECTIONS
}

\begin{abstract}
ANALYTICAL AND EXPERIMENTAL STUDIES SHOULD BE CONDOCTED TO EVALUATE THE INFLUENCE OF SEMI-RIGID CONNECTIONS ON THE BEHAVIOR OF STEEL FRAMES.
\end{abstract}

Connection behavior, the most important factor influencing bare frame behavior, requires special attention. It is the subject of several other recommendations in this report, e,g., B5, B6, and D1. A separate topic should be the influence of connections on frame behavior - as distinct from studies of the characteristics of connections as individual elements. Of particular concern is the influence of partially rigid connections. This research should include an evaluation of the available analytical models and experimental data on the moment rotation characteristics of semi-rigid connections. Existing computer programs for including connection flexibility should be studied, evaluated, and extended. Further research should be conducted on the influence of connection rigidity on column stability. A major effort should be made to extend this research into the determination of the influence of connection rigidity on overall, three dimensional frame behavior. This should be related to the analytical and experimental research called for in RECOMMENDATION Cl.

A multi man-year effort is required.

\section{RECOMMENDATION C3: CLADDING AND INFILLING}

\author{
ANALYTICAL AND EXPERIMENTAL STUDIES SHOULD BE \\ CONDUCTED ON THE INFLUENCE OF FLOORS, PARTITIONS, \\ AND CLADDING ON STIFPNESS AND STRENGTH.
}

It is well known that the various types of infilling control the ways in which loads are transmitted to the steel frame and that they often interact structurally with the frame in resisting 
these loads. Infilling can offer major - even dominant resistance to displacement at service loads and it can also contribute significantly to the ultimate resistance of the total building system. At present this influence is either ignored, accounted for by judgment, or calculated in some ad-hoc approximate way. Many studies have been made on the stiffness and strength of different types of floors, partitions, and exterior cladding in direct tension and compression, flexure, and shear (racking and diaphragm action). Relatively little quantitative research has been done on infilling-frame interaction however.

There is a need to extend analytical models of the type called for in RECOMMENDATION Cl to include the effect of infilling. Associated with this is the need to collect and correlate available quantitative information on the structural characteristics of major types of infilling. Laboratory testing of three dimensional steel frames containing representative infill elements should be conducted for the purpose of calibrating or confirming analyses.

A multi man-year level of effort is required.

\section{RECOMHENDATION C4: IATERAL DEFLECTION}

\section{ANALYTICAL METHODS SHOOLD BE DEVELOPED FOR CAICOLATING IATERAL DEFLECTIONS OF BOILDINGS.}

Related to the previous three recommendations but having a different major thrust is the need to develop improved analytical methods for the calculations of lateral deflection under both static (or quasi-static) and dynamic (wind and earthquake) loads. Experience has shown that the lateral deflection of low to medium rise steel buildings subjected to wind loading is often far less than predicted by conventional analytical methods. Recent studies suggest that the discrepancies between observed and calculated drift are not due to the methods of assessing wind loading but must be accounted for by structural actions. Conversely, some tall buildings have experienced undesirable, uncalculated lateral motion effects. Analytical methods that include the features described in RECOMMENDATION Cl to C3 (three dimensional behavior and the influence of connections and infilling) and realistic first and second order elastic static and dynamic response characteristics are needed. These methods should be used in studies directed toward the establishment of realistic drift criteria or guidelines for wind loading and moderate earthquake loading.

A multi man-year level of effort is required. 


\section{RECOHMENDATION C5: FIELD MEASUREMENTS}

\section{FIELD MEASUREMENTS OF THE RESPONSE OF ACTUAL BUILDINGS SHOULD BE MADE.}

Most research is effectively conducted under the controlled conditions obtainable either in the laboratory or in analysis of systems of specified geometry, element properties, and support conditions, under prescribed loading. Nevertheless, studies of analytical or physical models can never fully duplicate the behavior of actual buildings. Although field measurements of building response cannot be the primary basis for research, they are essential for the purpose of calibrating, correcting, or exposing the imperfections of laboratory and analytical research.

Buildings in earthquake and hurricane regions have been instrumented, but additional efforts of this type are needed. They should be long range studies and they should be correlated with controlled environment (laboratory or analytical) research. The phenomena studied should include relative resistance of frame and infilling, frequencies, drift, twist, acceleration and other factors that influence the serviceability or strength of the total system.

A multi man-year level of effort is required.

\section{RECOMENDATION C6: COMPOSITE CONSTRUCTION}

\section{ANALYTICAL AND EXPERIMENTAL STUDIES SHOULD BE CONDUCTED TO ESTABLISH THE BEHAVIOR OF COMPOSITE STEEL-CONCRETE FRAMING SYSTEMS AND BLENENTS.}

One of the most pronounced recent trends in tall building construction has been in the direction of using structural steel and reinforced concrete in combination as primary structural elements. The composite tubular system has become increasingly popular in the construction of tall buildings over the past few years. In this system the framed tube, consisting of closely spaced reinforced concrete exterior columns and deep spandrel beams made of reinforced concrete or structural steel, resists lateral loads produced by wind and/or earthquake. Structural steel framing supports the gravity loads. The steel floor members are connected to small steel columns which are embedded in the reinforced concrete exterior columns. The efficiency of this system is attributed to the advantageous use of the best characteristics of both steel and concrete. The steel floor framing is light and, as a result, smaller interior steel columns are needed. In addition, the light framing provides flexibility for space planning, particularly in the core. Above all, the steel frame can be erected rapidly. The economy of the tube system with steel spandrels has been proven, and a few buildings 
in Dallas and Houston, Texas have already been constructed with this combination. In about 90 percent of the tube designs to date, reinforced concrete spandrels have been used mainly because of the uncertainties associated with the connection between a steel beam and a concrete column.

Research is needed on the overall performance of composite framing systems in addition to work on individual composite elements such as beams and columns. The three-dimensional performance of these systems, time-dependent changes in stiffness, damping characteristics, and stiffness changes under dynamic loads require study. An experimental and analytical parametric study is also needed to determine efficient means of developing the moment capacity of the steel spandrel beams at the steel beam-concrete column joint and to determine the rigidity of the joint itself.

A multi man-year effort is required.

\section{RECOMHENDATION C7: COLD-FORMED CONSTROCTION}

\section{EXPERIMENTAL STUDIES SHOOLD BE CONDUCTED TO BSTABLISH THE BEHAVIOR OF MULTI-STORY FRAMING SYSTEMS USING COLD-FORMED STEBL HEMBERS.}

Cold-formed members are starting to be used for multi-story buildings up to five stories. Such construction offers opportunities for innovative design concepts including "monocoque" construction, improvements in incorporating architectural and mechanical elements with the structural system, and more effective use of material and improved structural efficiency resulting from the ability to control the shapes of members.

Analytical and experimental research is needed to address aspects of the following problems unique to cold-formed members in building frames: local and overall stability of members, connections including adhesive bonding, diaphragm action, composite construction using mixed materials (wood-metal, fiber reinforced materials - metal, etc.) and prefabricated assemblies.

A multi man-year effort is required.

\section{RECOMENDATION C8: NON-COMPACT SECTIONS}

RBSEARCH SHOULD BE CONDUCTED TO DETERMINE IF

MOWENT REDISTRIBUTION CAN BE UTILIZED TO

ADVANTAGE IN PRAMES COMPOSED OF NON-COMPACT

SECTIONS.

A large percentage of low-rise steel construction utilizes 
non-compact members in the framing systems. Significant costsavings could be achieved if the principles of moment redistribution commonly used in plastic design could be applied to such structures.

The following research is needed:

- Study of analysis methods to determine failure mechanisms in typical low-rise frames composed of non-compact sections.

- Comparison of frames designed using moment redistribution with frames using elastic analysis.

- Full-scale tests of frames designed using moment redistribution to confirm procedures.

A two man-year level of effort is required.

\section{SEISMIC DESIGN}

Approximately three-fourths of the annual construction investment in the United states is in some 40 states that have experienced moderate or major earthquakes in the past. Seismic design is obviously an important consideration for steel buildings. Earthquake related research has been conducted on steel structures. Additional work is needed to estblish the behavior of connections and individual members and the performance of structural systems subject to large inelastic cyclic deformations of the type produced by earthquake loading.

\section{RECOMHENDATION DI: BEHAVIOR OF SEMI-RIGID CONNECTIONS}

\section{AN BXPERIMENTAL AND ANALYTICAL RESEARCH PROGRAM SBOULD BE UNDERTAREN TO EVALUATE THE INELASTIC CYCLIC PERFORMANCE OF SEMI-RIGID BUILDING CONNECTIONS.}

studies are needed to quantify the cyclic hysteretic behavior of semi-rigid beam-to-column connections in building structures designed for conditions of low to moderate earthquake loadings. Specific topics of needed research include: 
- Cyclic tests of various types of semi-rigid connections (end plates, cap and seat angles) to determine their mode(s) of distress (local instability, fatigue), and to quantify their moment-rotation response and hysteretic energy absorption capability under repeated displacement excursions.

- Develop analytical models to predict the non-linear response of connections of varying stiffness, and generate computer programs to assess the inelastic cyclic response, including resistance to incremental collapse, of a complete building system.

- Determine efficacy of available low cycle fatigue relationships and cumulative damage models to predict the cumulative effect of seismically induced inelastic displacement excursions on the connections.

A multi man-year effort is required.

RECOMMENDATION D2: DRIFT CONTROL CRITERIA
STUDIES SHOULD BE UNDERTAREN TO CORRELATE
SERVICE LOAD WIND DRIFT CONTROL CRITERIA
WITH LATERAL DISPLACEMENT PERFORMANCE ONDER
EARTHQUARE LOAD HISTORIES FOR FLEXIBLY-
CONNECTED BOILDING FRAMES DESIGNED IN
REGIONS OF LOW TO MODERATE SEISMICITY.

Flexibly-connected (AISC Type 2) frames are common in low rise building structures designed primarily for drift control from wind at service loads. Research is needed to evaluate their inelastic lateral displacement behavior under seismically induced ground motions. Studies are required in the following areas:

- Develop a rational method for calculating lateral displacements (wind drift) at service loads in Type 2 building structures, including the contribution of cladding and other non-structural elements to overall frame behavior (see RECOMMENDATION $\mathrm{C} 2$ and $\mathrm{C} 4$ ).

- Develop analytical models to assess the inelastic cyclic lateral displacement performance (including consideration of frame instability and incremental collapse) of flexibly-connected frames under earthquake load histories.

- Formulate design guidelines for flexibly-connected building frames (including connection strength and ductility requirements, panel zone shear deformation limits, bracing requirements, etc.) to ensure adequate drift control at service loads, and to satisfy 
ductility, strength, and stability demands for extreme loads during a seismic event.

A multi man-year level of effort is required.

\section{RECOMMENDATION D3: SEISMIC PERPORMANCE}

\section{A RESEARCH PROJECT SHOULD BE UNDERTAREN TO SUMMARIZE EXISTING PERFORMANCE DATA FOR STEEL BOILDINGS SUBJECTED TO SIGNIFICANT RARTHQUARES.}

Steel buildings which were not designed in accordance with today's seismic design criteria have survived significant earthquakes sustaining little or minor damage. Examples of earthquakes where steel buildings survived and data are available include San Francisco, Caracas, Mexico City, Managua, Guatamala and several Japanese cities. The design profession and code writers do not have the resources to evaluate past performance because documentation is scattered. The work should include:

- Review reconnaissance reports and identify types of steel building construction and relative damage.

- Compare types of construction with current seismic design procedures and determine if the structures were in general conformance with code philosophy. If not, identify reasons for lack of expected damage.

- Identify information that can be readily used for code development and design.

- Analyze past performance of various construction systems and review the need for fully ductile systems.

A one man-year level of effort is required.

\section{RECOMMENDATION D4: STEEL STUD WALLS}

A COMPREHENSIVE RESEARCH PROGRAM SHOULD BE UNDERTAREN TO DETERMINE THE ALLOWABLE SHEAR RESISTANCE OP WALL SHEETING MATERIALS COMMONLY OSED WITH COLD FORMED STEEL STUD WALLS.

Load-bearing steel stud wall systems are commonly designed for lateral force resistance using flat strap acting as in-plane bracing. Limited work has been done to determine the allowable shear force resistance provided by sheeting material such as wallboard, lath and plaster and plywood. 
Past research has provided 1 imited data for use with lath and plaster, plywood and wallboard shear walls. No work has been done to evaluate the effectiveness of the bracing systems used in conjunction with these common sheeting materials. An advantage of steel studs in building construction is their non-combustible classification. However, only plaster or wallboard materials are currently used in these non-combustible classifications since plywood is combustible. Unfortunately, plaster and wallboard have relatively low shear resistance. Other options need to be investigated. The following work is needed:

- Develop a wide range of shear values for common sheeting materials by studying the effects of varying attachment spacing, steel stud base metal gage and various anchorage details.

- Develop a methodology for calculating the allowable shear value for untested materials.

- Study the effects of combining the braced frame and wall sheeting materials.

- Investigate anchorage details and their impact on allowable loads.

- Develop new non-combustible shear resisting systems such as steel sheet shear walls using tension field action.

A multi man-year effort is required.

\section{RECOMMENDATION D5: BEAM-COLUMN JOINTS}

AN INTEGRATED EXPERIMENTAL AND ANALYTICAL
RESEARCH PROGRAM SHOULD BE ONDERTAREN TO
CLARIFY CYCLIC BEHAVIOR AND RELIABILITY OF
BEAH-COLOMN JOINTS HAVING BEAM-TO-COLOMN
FLANGE CONNECTIONS AS WELL AS THOSE ATTACHED
TO A WEAR COLOMN AXIS.

Moment-Resistant Frames are predominant in seismic design of steel frames. In addition to their conventional use, they are also employed in the perimeter framing of tall buildings. The critical element in such framing is the joint, i.e., the entire assemblage at the intersection of members. The connection consisting of those elements that connect the member to the joint, which may be affected by the behavior of the entire joint, is usually the most critical element of the assemblage. In spite of the wide use of such joints, the seismic design criteria are poorly defined, and there is a considerable degree of uncertainty regarding their capacity. Very limited research information is available on the cyclic behavior of joints of realistic size. Due to competitive pressures, inadequate designs are sometimes 
accepted even for new frames. There is no real consensus, and it is essential to clarify for the designers the proper bounds.

The following research is needed:

- Carry out analytical studies for the design of experiments to simulate the relevant size range of beam-column connections. This study should be supplemented with inelastic dynamic frame analyses to determine the bounds on joint loadings.

- Design and carry out two-dimensional experiments on joints of realistic sizes (approximately half-size and larger) for connections of two types:

a. Beam-to-column flange connections

b. Beam-to-column web connections

For either type, the all-welded as well as connections with bolted web and welded flanges should be studied. The possibility of reinforcing bolted webs with welding to inhibit bolt slip should be explored.

- Extend the the two-dimensional studies to three dimensions.

- Formulate practical rules for sizing panel zones, stiffeners (continuity plates), as well as flange and web connections.

A multi man-year effort is required.

\section{RECOMMENDATION D6: BEAM-COLUMNS}

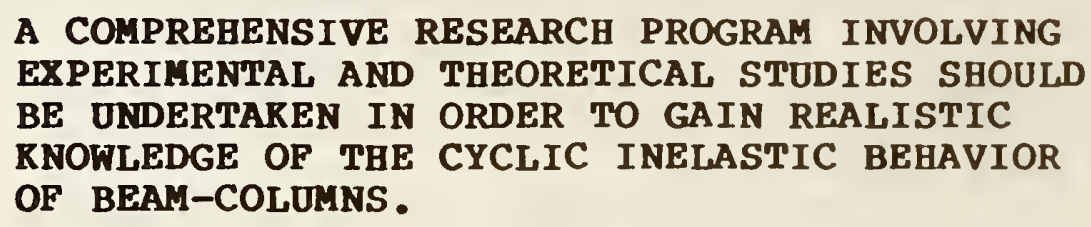

Although it would not be desirable to design beam-columns for inelastic cyclic buckling, analytical tools are needed to represent their behavior when studying inelastic dynamic response of structures subjected to severe earthquake motions. In braced frames with relatively heavy bracing members the columns may be subjected to large cyclic axial forces and moments which may lead to overall structural instability. The research work to date on beam-column behavior has been almost exclusively devoted to unidirectional loading. In the absence of data on the cyclic behavior of beam-columns, a few attempts have been made to formulate simple models derived from the knowledge of behavior of beams and bracing members. 
The research should involve the following:

- Effect of end conditions.

- Effect of strength and stiffness of columns in comparison to that of beams.

- Loading history to include ratio of end moments as well as their magnitudes relative to axial force.

- Effect of geometrical properties.

- Experimental work should include small scale and full scale members, as well as subassemblages and prototypes.

- Analytical work should be aimed at development of realistic and practical hysteresis models for analysis purposes, as well as development of design criteria to alleviate structural instability.

A three to five man-year level of effort is required.

\title{
RECOHMENDATION D7: TUBULAR HEMBERS
}

\begin{abstract}
A COMPREHENSIVE RESEARCH PROGRAM INVOLVING EXPERIMENTAL AND THEORETICAL STUDIES SHOULD BE ONDERTAREN IN ORDER TO EVALUATE THE DUCTILITIY AND ENERGY DISSIPATION CAPACITY OF STEEL TUBULAR MEMBERS SUBJECTED TO LARGE CYCLIC DEFORHATIONS.
\end{abstract}

Cold formed rectangular steel tubes have gained popularity in recent years especially as bracing members in multistory frames. Lighter structures utilize these shapes for columns and beams as well. In a few past studies it has become quite clear that under cyclic loading severe cross section deformation in regions of plastic hinges leads to local buckling and premature failures. Concrete filling is one way to delay this mode of failure. The concrete inside the tubes prevents severe local buckling of steel tubes while the tube itself gives excellent confinement to concrete. Some preliminary work has produced very promising results. Research is needed to study the hysteresis behavior and modes of failure under different cyclic load conditions. Theoretical procedures should be developed to synthesize the hysteresis models and establish design criteria for such composite members.

The research should involve the following:

- Effect of confinement via relationship between the area or volume of steel and concrete. 
- Effect of bond between steel tube and concrete.

- Effect of relative strength of steel and concrete. Normal strength, high strength and light weight concrete should be included.

- Effect of width-thickness ratio of tube walls.

- Effect of different loading histories.

- Experimental work should involve:

a. Reduced scale as well as full scale specimens

b. Beams, columns, and bracing members

c. Connections

d. Subassemblages and prototypes

- Development of analysis techniques and design criteria.

A multi man-year effort is required.

\section{RECOMHENDATION D8: END-PLATE BEAM-TO-COLUMN CONNECTIONS}

\section{DESIGN CRITERIA AND PROCEDURES SHOULD BE DEVELOPED FOR END-PLATE MOMENT CONNECTIONS SUBJECTED TO BARTHQUAKE MOTIONS.}

In recent years, considerable experimental and analytical research has been conducted on the behavior of end-plate moment connections under static loading. Some limited work has been done in Italy and New Zealand on the behavior of moment end-plate connections under cyclic loading; however, design rules have not been formulated. Still these connections are being used in buildings located in moderate to severe earthquake areas. Thus, there is need for a comprehensive study of the cyclic behavior of end-plate connections for safety reasons.

Research is needed on the cyclic behavior of moderate to large capacity, 4- and 8-bolt, extended configurations as used in multi-story frames. End-plate thicknesses for these connections are typically between $3 / 4$ in. and 2 in. and corresponding bolt diameters are between $3 / 4$ in. and $1-1 / 2$ in. The experimental work should consist of subjecting full-scale, end-plate connected beam and column assemblies to severe cyclic loading. The loading must simulate the effects of strong earthquakes. Major parameters of the study should be end-plate geometry, grade of steel, bolt diameter and bolt type, and the random nature of earthquake cyclic effects. Analytical studies should include the development of a finite element model and associated coding to predict the connection behavior. The finite element model must account for the effects of nonlinear material properties and possible plate separations at the end-plate/column flange interface. Portions of both the beam and column must be modeled. 
A two to three man-year level of effort is required.

\section{RECOMMENDATION D9: BOLTED WEB MOMENT CONNECTIONS}

\section{LOW CYCLE FATIGUE LIFE OF BEAM-TO-COLUMN MOMENT CONNECTIONS MUST BE INVESTIGATED TO PROVIDE A RELIABLE BASIS FOR SEISMIC DESIGN.}

In seismic design of ductile moment resisting frames, beamto-column moment connections must be capable of developing the full plastic capacity of the beam section unless it can be shown that adequate ductility is provided by a lesser connection. For reasons of economy, it is common practice to use full-penetration flange welds and friction-type bolted web connections. Due to slippage of the bolted web connections under a combination of high moment and shear, the beam flanges must develop the plastic moment capacity of the section at the beam-to-column connection. While welded-flange, bolted-web connections have been found to exhibit considerable ductility, their low-cycle fatigue life under large inelastic deformations is not as good as that found for fully welded connections. In a strong motion earthquake, even a symmetrical structural system is likely to behave unsymmetrically. In reality, then, the welded-flange connections will be subjected to out-of-plane bending and torsion. The lowcycle fatigue life of the beam-to-column connections will be influenced by the additional stresses. For a reliable prediction of the three-dimensional behavior of real buildings, the hysteretic behavior of moment connections under three-dimensional deformations must be known. Since such predictions must be carried out by computer, a reliable analytical model of connection behavior is necessary.

The proposed study would have a comprehensive experimental program and an analytical counterpart. The experimental work would require testing of a variety of connection configurations, under several three-dimensional load histories. The configurations should represent a range of member sizes and the loads should simulate the inelastic three-dimensional response of a real building under a strong motion earthquake. The development of an analytical model for the representation of connection behavior should be carried out in conjunction with the experimental program. The analytical model should capture the dominant behavior of this type of connection under extreme cyclic deformations. When implemented in a computer program, the model should permit a reliable assessment of the behavior of a complex structure including its resistance to incremental collapse.

A three to four man-year level of effort is required. 


\section{RECOHHENDATION D10: BRACING CONNECTIONS}

\section{ANALYTICAL AND EXPERIMENTAL STUDIES SHOULD \\ BE UNDERTAREN TO ESTABLISH THE PERPORMANCE \\ OF GUSSETED BRACING CONNECTIONS.}

Diagonal bracing provides an efficient means of resisting lateral loads both in tension and compression. The ability of these members to yield and buckle in a controlled manner provides substantial increased energy absorption to the structural system. Much work is needed to understand the fundamental behavior and modes of failure of gusseted bracing connections and their influence on the response of the bracing and total structural system.

The research should include:

- Single diagonal and $\mathrm{X}$-braced diagonal configurations with various structural shapes, such as single angles, double angles, channel sections, rectangular tubes, circular tubes (pipes), and wide flange sections.

- In-plane and out-of-plane buckling behavior should be studied to determine the connection detail differences and bracing behavioral differences for these systems.

- Both concentric and eccentric brace connection details should be included in this program.

- Gusset plate connections should include the appropriate attachments to the associated beams and columns as well as to the braces. Welded and bolted connection details are needed.

- Experimental studies at full and reduced scales should be conducted to establish reliable data for the development of design recommendations.

- Theoretical and analytical studies to explore the dominant behavioral characteristics of gusset plate connected bracing members should be conducted in concert with the experimental studies.

- Design procedures, recommendations, and specifications should be developed to ensure satisfactory performance of the connections under severe earthquake ground motions.

A four man-year level of effort is required. 


\section{RECOMHENDATION D11: VISCOELASTIC DAMPING}

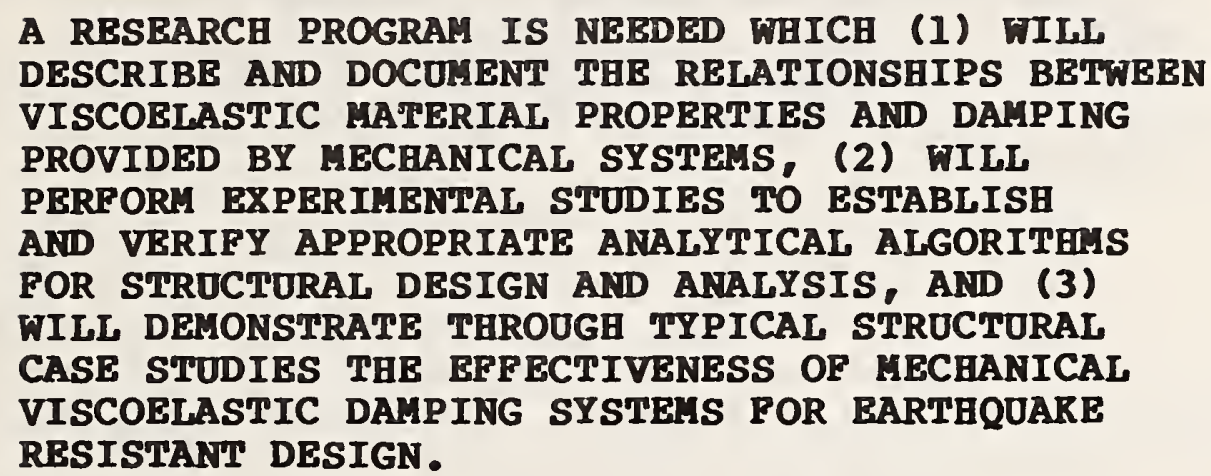

Mechanical damping systems can dissipate significant amounts of energy during vibratory motions. It is well known that structures subjected to severe earthquake ground motions must dissipate some of the input earthquake energy through nonlinear material damping. By adding mechanical viscoelastic damping it is possible to reduce the structural vibrations caused by earthquakes and the amount of structural and nonstructural damage.

The following research is needed:

- Develop mechanical damping systems which utilize viscoelastic materials for energy absorption. These can be of the direct shear type, rotary shear type, or other.

- Experimentally determine the characteristics of full size mechanical viscoelastic damping systems.

- Establish appropriate analytical algorithms for these damping systems. The analytical algorithms would be used for design purposes and analytical verifications of the dynamic response characteristics of complete building systems.

- Conduct a parameter study to determine the optimum amount of mechanical damping to be added to various structural systems in order to minimize economically the earthquake hazard for these systems.

- Develop recommended procedures for the design of mechanical damping systems considering ease of application by the design profession.

- Extend the results to retrofit of existing buildings and design for strong winds.

A multi man-year effort is required. 


\title{
RBSEARCH SHOULD BE CONDUCTED TO QUANTIFY DOCTILITY DEMANDS AND CAPACITIES FOR STROCTURAL SYSTEMS, ELEMENTS AND CONNECTIONS AND DEVELOP CRITERIA FOR PERPORMANCE ASSBSSMENT.
}

Deterioration in strength of elements of steel structures is often a consequence of localized failures, such as crack propagation and fracture at connections, or localized instabilities (local and lateral torsional buckling) within members. The deterioration caused by these localized failures is a function of the number and magnitudes of inelastic excursions. The profession and code writing bodies need information that permits a quantitative assessment of seismic performance in order to develop acceptable detailing criteria. Consideration must be given to the randomness of seismic input and the cumulative effects of inelastic excursions on structural damage. Cumulative damage models, of the type used extensively in mechanical engineering, can provide much of the needed information.

The following research is needed:

- Evaluation of the number and magnitudes of inelastic excursions a structure or structural element is expected to experience in an earthquake.

- Development of cumulative damage models for structural elements based on low-cycle fatigue concepts.

- Conduct laboratory tests to validate damage models.

- Development of representative cyclic loading histories for testing, so that test results can be generalized to damage prediction under random loading histories.

A three man-year level of effort is required.

\section{RECOMHENDATION D13: BRACED PRAMB STABILITY}

\begin{abstract}
ANALYTICAL AND BXPERIMENTAL STUDIES SBOULD BE CONDUCTED TO DETERMINE THE STABILITY OP BUILDING SYSTEHS WITH THE LATERAL PORCE RESISTANCE PROVIDED BY $R$ OR CHBVRON BRACING.
\end{abstract}

One of the basic concepts of seismic design is that if the building system is designed to respond in an inelastic manner to ground shaking having an intensity much larger than the yield level of the structures, the structure should yield without undergoing collapse. Building systems using $\mathrm{K}$ or Chevron bracing 
for lateral resistance of seismic forces and movements frequently have been used in areas of high probability of strong seismic shaking. In the $K$ braced system, the column to which the apex of the brace is connected continuously supports vertical dead and live loads. If the compression segment of the brace were to buckle, the column would have additional forces induced by the remaining brace segment which are not usually accounted for in design. Similarly, the Chevron brace would induce forces into the horizontal flexural member which are not usually considered in design.

Analytical and experimental work should determine the inelastic behavior of these bracing systems and appropriate design criteria should be established to provide adequate stability during large intensity earthquakes.

A two man-year level of effort is required.

\title{
RECOHHENDATION DI4: LATERAL BRACING
}

\begin{abstract}
AN EXPERIMENTAL STUDY SBOOLD BE CONDOCTED TO DETERMINE ILATERAL SOPPORT REQOIREMENTS FOR MEMBERS SOBJECT TO SIGNIFICANT INBLASTIC RESPONSE DURING EARTHQUARES .
\end{abstract}

There have been numerous tests of subassemblages composed of steel beams and columns. In almost all cases the lateral supports of the members tested were not under study. Thus the lateral supports provided were essentially rigid and closer together than needed. Over the years there have been many studies to determine the spacing of lateral support members. These tests, however, do not provide the information needed to evaluate the requirements for lateral bracing properly for members undergoing the potentially large inelastic deformations required for members in areas of high seismicity.

New experimental research should be conducted to determine the design requirements for members of seismic frames having reversing, high moment gradients and non-linear response characteristics. The tests should also consider the lateral support offered by a composite floor slab. A variety of bracing configurations should be studied.

A multi man-year effort is required. 


\section{RECOMMENDATION D15: OVERALL SYSTEM RESPONSE}

\section{AN INTEGRATED ANALYTICAL RESEARCH PROGRAM SHOULD BE UNDERTAREN TO DETERMINE THE THREE-DIMENSIONAL EFFECTS IN THE NONLINEAR RANGE OF ARCHITECTURAL AND STRUCTURAL CBARACTERISTICS OF IRREGULAR BUILDINGS IN ORDER TO DETERMINE THEIR CAPACITY TO RESIST EARTHQUARES OF VARYING LEVELS OF SEVBRITY.}

Architects are becoming conscious of the importance of including earthquake resistance considerations in their conceptual designs. Architectural concepts take advantage of the versatility of steel framed structures, and the use of configurations involving setbacks, asymmetry, and combinations of shear walls and moment frames is quite common. There is very limited quantified information on strength and drift for various types of building concepts. Architects as well as engineers need data on bounds for irregularity, interaction of structural and non-structural elements, and effects of mixed structural systems. Torsion, relative importance of shear walls and frames in the nonlinear range, and interaction of the structural frame with non-structural elements, such as curtain walls, are effects that are best investigated through three-dimensional models. Analyses that utilize computer software for three-dimensional nonlinear analyses can be very helpful in determining drift and strength characteristics of structures that cannot be reliably modeled in two dimensions. An additional benefit of three-dimensional analyses is to establish 1 imits on setbacks, asymmetry, etc., within which two-dimensional modeling gives acceptable results.

The following research is needed:

- Documentation of architectural systems for low-rise buildings that incorporate features which require three-dimensional evaluation.

- Classification of structural systems into groups that are susceptible to analysis with existing software.

- Evaluation of structural systems for which new software or modified software needs development.

- Analysis of typical structures from each classification to determine their response characteristics into the nonlinear range.

- Engineering investigations, utilizing the results of analysis, to establish bounds on drift and strength requirements for categories of building concepts.

- Guideline documents that architects and engineers can use for design. 
A five man-year level of effort is required.

\title{
RECOHANDATION DI6: EVALOATION OF BXISTING BOILDINGS
}

\author{
AN EXPERIMENTAL AND ANALYTICAL STODY SHOOLD BE \\ CONDUCTED TO ESTABLISH LEVELS OF SEISHIC RESISTANCE \\ OF LON-RISE STEEL FRAME BOILDINGS, AND PROCEDURES \\ SHODLD BE DEVELOPED TO STRENGTHEN THEM HHERE \\ NECESSARY TO ACCEPTABLE LEVELS.
}

Initial emphasis on retrofit and strengthening of existing buildings has been on unreinforced masonry buildings. Whereas it was originally felt that such buildings had to be demolished, recent experimental and analytical work showed that it was possible to strengthen them and make them earthquake resistant. The economics of strengthening such buildings was a major consideration in this evaluation. Although low-rise structural steel buildings are less susceptible to damage, their level of earthquake resistance has not as yet been demonstrated through experiments and analysis. Dynamic analyses of buildings to calculate their response to earthquake excitations is now a routine procedure, but the emphasis has been on the analysis of structures that are being designed for new construction. It is necessary to investigate existing structures to find their earthquake resistance capacity and to develop methods of retrofit to bring their resistance up to acceptable levels.

An extensive analytical and experimental program should be carried out to identify the seismic resistance capacity of existing steel structures of various typical configurations that have not been designed to present seismic codes. The experimental work should consist of testing existing buildings and laboratory experiments of framing that corresponds to the structural systems of typical classes of existing buildings. Since existing buildings cannot be tested to destruction, information obtained from such tests must be supplemented by laboratory tests to determine the capacity of major elements of the structures. Subsequently, concepts should be developed for strengthening buildings found susceptible to damage at practical seismic excitation levels. Criteria should then be developed for economic methods of strengthening and procedures should be recommended for analysis and design to meet these criteria.

A six man-year level of effort is required. 


\title{
E. LOAD AND RESISTANCE FACTOR DESIGN
}

The proposed AISC Load and Resistance Factor Design (LRFD) specification for structural steel buildings was released for review and trial use in 1983. The LRFD specification is the prototype for a new generation of structural design codes. Research opportunities exist for facilitating and expediting implementation of the LRFD specification. They range from assembly of existing data to laboratory testing to resolve specific questions on topics where the new specification may be overly conservative.

\section{RECOMMENDATION EI: CONNECTIONS WITH OVERSIZE HOLES}

\begin{abstract}
AN ANALYTICAL STUDY SHOULD BE CONDUCTED TO DETERMINE THE INPLOENCE OF SLIP IN BOLTED CONNECTIONS ON FRAME GEOMETRY AND FRAME STABILITY.
\end{abstract}

The slip critical high-strength bolted joints are designed in LRFD at service loads and the nominal specified shear strength is the same as the allowable shear for such bolts in ASD. Thus, slip may occur at overloads. Is slip at overloads a strength/safety problem in such joints when built with oversized holes? The question arises in bracing connections in high rise buildings. It has been suggested that slip at overloads could distort the frame to such a degree that instability may occur.

Research along two lines of attack is needed: First, considering the random alignment of holes, how much slip will realistically occur in a multifastener joint? A reexamination of the existing test data is needed to assure that this problem is handled adequately in the specifications. Second, an analytical study is needed on the influence of slip in bolted connections with oversize holes on frame geometry to determine whether frame instability problems could result. The type and size of buildings for which higher bolt design values can be used in slip-critical connections should be determined.

A one-half man-year level of effort is required.

\section{RECOHHENDATION E2: WEB CRIPPLING}

EXPERIMENTAL STUDIES SHOULD BE CONDUCTED TO EVALOATE WEB CRIPPLING BEHAVIOR OF LIGHT BEAM SECTIONS WITH SEATED CONNECTIONS.

The proposed LRFD formula for web crippling at bearing ends of beams (i.e., seated connections or wall bearing beams) may seriously affect the use of seated connections. The web 
crippling capacity of some of the lighter sections (W14x22, W1 $2 \times 14$, W10x12) will be reduced well below the equivalent ASD capacity.

The LRFD specification requires that lateral support be provided at bearing ends. The present AISC manual infers that side clips or top clips must be used with seated connections. For the lighter sections, a typical side clip will not only provide the required lateral support but also will provide significant vertical load reaction capacity.

Tests should be conducted for the lighter beam sections to evaluate the contribution of the side and or top clip to web stability (see also RECOMMENDATIONS B3 and B4).

A one-half man-year level of effort is required.

\title{
RECOMMENDATION E3: TECHNOLOGY TRANSPER \\ TRACHING MATERIALS AND DESIGN AIDS SHOUID BE PREPARED TO ACQUAINT BUITDING OPFICIALS WITH THE USE OF ILRPD.
}

Rapid acceptance and use of LRFD is contingent upon building officials having a thorough understanding of the principles and details of this new design procedure.

Educational material should be prepared to teach the use of LRFD to building officials. It should include any special information or design aids needed by building departments to review and check LRFD designs. Video cassette type lectures and the establishment of a point of contact to respond to questions on details of the specification should be considered. Material should be prepared for administrative level officials and plan examiners.

A one-fourth man-year level of effort is required.

\section{RECOAMELDATION E4: RESISTANCE FACTORS}

\begin{abstract}
A SYSTEMATIC STUDY SHOULD BE ONDERTAREN TO COLLECT INFORMATION ON ACTUAL PRODUCTS AND STRUCTORES FOR USE IN COHPOTING RESISTANCE PACTORS FOR STRUCTORAL MEMBERS.
\end{abstract}

Data have been collected on the variation of geometrical and mechanical properties of steel members. A systematic assembly of these data for the broad range of steel products and fabricated structural elements has not been reported. Higher $\phi$ factors could be used for those cases where higher mean values or smaller coefficients of variation than presently used are obtained. 
The following research is needed:

- Systematic collection of data on the variations in the geometric properties of the major rolled shapes, tubes, fabricated sections, bolts and welds.

- Systematic collection of data on the variations in the mechanical properties of rolled shapes, plates, cold-formed and hot-rolled tubes, bolts, welding electrodes, and welds.

- Systematic collection of data on as-built imperfections, such as out-of-plumb, sweep, camber, etc., as a function of quality control.

- The calculation of $\phi$ based on the above data base for the various products and class of members and/or structures.

A three man-year level of effort is required.

\title{
RECOMARIDATION E5: SERVICEABILITY CRITERIA
}

\begin{abstract}
RESEARCH SHOOLD BE UNDERTAREN TO DEVELOP THE DATA BASE AND ANALYSIS PROCEDURES NEEDED TO PREPARE RATIONAL AND PRACTICAL SERVICEABILITY CHECKING PROCEDURES FOR LRPD.
\end{abstract}

The use of the computer as a design tool and modern architectural requirements have led to building systems that are flexible and lightly damped. Since structural stiffness has remained the same or declined as strength has increased, modern buildings and building systems are increasingly susceptible to objectionable static or dynamic structural movement. Present codes and standards offer little guidance on these problems. Serviceability is more an economic than safety issue, and serviceability requirements are negotiable between engineer, architect and building owner. Serviceability criteria need to be flexible and adaptable to different building use requirements. However, the present lack of any meaningful criteria may be interpreted by some to mean that serviceability is not important, which raises questions of professional responsibility. With the move to limit states design, serviceability will become an increasingly important and delicate regulatory and design problem.

The following research should be conducted:

- Serviceability limit states should be identified through surveys of building owners and occupants, and correlated with measurements of structural loading and response. Serviceability limits should be related to occupancy. 
- Dynamic properties of structural systems must be identified through a program to measure in situ static and dynamic structural response.

- Load combinations should be developed for checking deflections under static loads against tolerable limits.

- Simple serviceability checks must be developed to control objectionable structural motions, taking into account the load levels, the dynamic characteristics of the load, and the structural response.

A multi man-year effort is required.

\section{RECOHHENDATION E6: LATERAL MOTION CRITERIA \\ LIHIT STATE CRITERIA SHOULD BE DEFINED FOR THE LATBRAL HOTION OP BUIIDINGS AND PERPORHANCE CRITERIA DEPINED.}

Drift or lateral motion of buildings is an important design consideration. These criteria become a controlling factor for buildings greater than two to three stories. In the absence of wind tunnel tests, arbitrary limits are imposed for this drift in design. There is no information available to substantiate these limits. In many cases, these limits result in an economic disadvantage for steel structures.

Research should be conducted to define drift values associated with the following limit states: internal partition failure, elevator tolerances, human comfort and building crane operation.

A two man-year effort for three years is required.

\section{RECOHMENDATION E7: VIBRATION CONTROL FOR LIGHT FLOOR SYSTEMS}

TECHNIQOBS ARE NEEDED TO INCREASE THE DAMPING IN

FLOOR SYSTEMS WHICH WILL ALLOW REDUCTION IN

WEIGHT WITHOOT ADVERSELY AFPECTING THE

ACCEPTABILITY OF THE FLOOR WITH REGARD TO

ANNOYING, OCCUPANT-INDUCED FLOOR VIBRATIONS.

If the weight of steel beam- or steel joist-concrete slab floor systems is reduced, the savings in building costs can be significant due to the pyramiding effects of beam, column, and footing sizes. The obvious maximum effects on weight reduction are to decrease the concrete slab thickness, reduce the unit 
weight of the concrete or substitute a lighter material. The resulting reduction in mass will, however, have an adverse effect on the vibration characteristics of the floor system. Since damping is the most important vibration parameter for floor systems excited by normal office or residential human occupancy, the acceptability of an ultra-light floor system can be improved by increasing the system damping.

Research is needed on methods and/or materials that can be used to increase the damping in floor systems. The problem is difficult because of the extremely small amplitudes 10.030 to 0.050 in.) that are perceived by humans to be annoying. Fullscale floor systems would have to be used in the research and particular attention paid to the economics of the damping materials selected, as well as the cost of the installation technique. Pilot applications in existing buildings will also be needed.

A two to three man-year level of effort is required.

\section{RECOMMBNDATION E8: PLASTIC DESIGN \\ STUDIES SHOOLD BE ONDERTARBN TO DETERMINE IP THE LRPD SPECIPICATION CONTAINS ADEQUATE PROVISION FOR THE USE OF PLASTIC DESIGN.}

The LRFD Specification rules for plastic design have been incorporated as an integral part of the overall design provisions rather than presented in a section of their own. As a result, plastic design using LRFD is not as readily apparent as with the 1978 and earlier AISC Specifications.

A study is needed to develop guidance for plastic design using LRFD. The results should be presented in a series of papers illustrating the use of plastic design concepts with the LRFD provisions.

A one-quarter man-year level of effort is required.

\section{RECOMHENDATION E9: SYSTEM RELIABILITY}

RESEARCH SHOULD BE UNDERTAREN TO DEVELOP THE ANALYSIS PROCEDURES AKD DATA NEEDED TO TARE ADVANTAGE OF SYSTEM BEBAVIOR IN LRPD.

Development of LRFD and supporting reliability analyses have focused on behavioral models and statistics for individual members. While these behavior models are believed to be realistic for describing response of individual members under design loads, they ignore the fact that such members are integral to a system, the behavior of which under extreme loads is 
complex. In certain highly redundant structures the system reliability is considerably higher than that of any individual member; in other systems, the system reliability may be less. since one of the ultimate goals of LRFD is more uniform reliability for all structures, it is plain that systems effects should be considered in some way.

The following research is needed:

- Establish realistic limit states for systems in terms of the member limit states which are known.

- Develop and validate procedures for computing system reliability.

- Develop criteria to take systems effects into account in design through the use of partial factors or other simple devices to reflect the mode and consequence of system failure.

A multi man-year effort is required.

\section{RECOMENDATION E10: WIND AND SEISMIC BPPECTS}

\section{RESEARCH SBOULD BE CONDUCTED TO ESTABLISH A RATIONAL AND CONSISTENT BASIS FOR WIND AND SBISMIC BFFECTS IN LRPD.}

The application of LRFD to buildings subjected to wind and seismic effects has not been thoroughly considered. In considering wind effects, wind directionality and structural enveloping have been taken into account only in an approximate fashion. The seismic analyses consider the ability of the structural system to dissipate energy through inelastic cyclic deformation in a rudimentary way. Moreover, unlike the limit states for gravity loads, the limit state for seismic effects consists of some poorly defined deformation limit. The present static-for-dynamic reliability analyses indicate lower reliabilities for wind and seismic effects than for other loads. Research data presently are insufficient to determine whether these discrepancies are real or only apparent, and they could not be resolved in developing the current LRFD specification.

The following research is needed:

- Identify appropriate limit states for earthquakes.

- Develop reliability analyses that take into account time-dependent nonlinear behavior explicitly. 
- Examine wind-directionality effects on the reliability of wind-sensitive structures.

- Develop equivalent lateral force requirements and performance requirements.

- Coordinate LRFD with wind and earthquake engineering communities.

A multi man-year effort is required.

\section{RECOMMENDATION EII: EXISTING BUILDINGS}

\section{RESEARCB SHOULD BE CONDUCTED TO BXTEND LARPD \\ TO INCLUDE STRENGTHENING AND REBABILITATION \\ OF EXISTING STRUCTURES.}

The proposed LRFD Specification was developed essentially for the design of new buildings. For example, the material characteristics used in the development of LRFD were derived from tests of current and recently replaced materials. However, everyday design practice requires the application of specification provisions to older structures for repairs, renovation etc. Research specifically directed to this problem will extend the applicability of LRFD to this area of design.

The following work is needed:

- Development of a systematic method for evaluation of material properties of existing structures. Note that these properties are likely to be very different from present day materials, and a statistically based sampling procedure may be desirable.

- Development of methods of evaluating resistance factors and reliability indices for structural components that were built by very different construction methods as well as factors for different classes of connections.

- Possible consideration of reduced life expectancy for existing structures and evaluation of such implications on load factors and reliability. Consideration of the value of past performance of the building on the LRFD evaluation.

- Formal application of the method to existing structures through development of an applications manual or example calculations.

A multi man-year effort is required. 


\section{F. PIRE PROTECTION}

Research opportunities exist for reducing the costs of providing fire protection for steel structures while maintaining current levels of safety. The work would also provide a more rational basis for fire protective design. It includes the development of analytical design procedures, design aids, new fire protective materials and fire models for special structures.

\section{RECOHMENDATION PI: PIRE RESISTANT DESIGN}

\section{A COMPREHENSIVE ENGINEERING DESIGN PROCEDURE SBODLD BE DEVBLOPED FOR EVALOATING THE PERFORMANCE OP STEEL FRAME BOILDINGS UNDER FIRE EXPOSURE CONDITIONS.}

In many cases current design criteria based on arbitrary limits such as the imposition of limits on steel temperature are overly conservative. During the past two decades, our understanding of fire phenomena and their impact on buildings has increased dramatically to the point where it is now possible to design specific buildings for anticipated fire conditions in a manner analogous to current structural design. Unfortunately, the procedures and techniques for accomplishing an integrated fire resistant design are not readily available to the design community. Performance criteria such as deflection limits and required strength conditions have not been developed. Current fire resistance requirements also do not take into account the probabilistic nature of fire occurrence in a manner comparable to other extreme loads such as earthquakes and extreme winds.

A design procedure should be developed using a load and resistance factor format. This will involve an analytical study modeling structural response taking into account stability problems, large deflection theory, occupancy and fire loading, influence of other fire protection features, and compartment geometry and ventilation. Design limit states and load combinations will need to be definied. The Fire Analys is of Steel Building Systems (FASBUS II) computer program should be used as a basis for this work.

A five man-year level of effort is required.

\section{RECOMMENDATION F2: DESIGN AIDS}

DESIGN AIDS SHOOLD BE DEVELOPED FOR CALCULATING PIRE PROTECTION MATERIAL THICKNESSES POR STEEL BOILDING ELEMENTS.

Hundreds of ASTM Ellg fire tests for establishing fire resistance ratings for steel columns, beams, floors, roofs and 
walls have been conducted. Such tests are expensive and time consuming, and each test has a limited application by virtue of the construction details of that particular tested construction. Test data are available which can provide a basis for developing analytical methods to predict fire resistance ratings for these building elements. This will provide an economical method for determining fire resistance ratings for untested steel constructions which differ in construction details from those tested. In addition, the ASTM Ellg test of floors and roofs identifies two fire resistance ratings - restrained and unrestrained. In order to prove that most steel floor designs in a building are restrained, AISI developed the FASBUS II computer program. Many code authorities require an analysis of the floor system using FASBUS II to prove the floor system is restrained. Design aids can reduce the need for an analysis of every floor construction.

Analyses should be conducted to determine the structural response of typical steel floor systems under fire exposure conditions. FASBUS II can be used for this. Full-scalefire tests may be required to provide additional data or verification of equations for an engineering guide. This information should be used to develop a simple guide for the structural engineer and building official to agree on the use of restrained test results to establish fire protection material thicknesses on steel floors and steel framing.

A two man-year level of effort is required.

\section{RECOHMENDATION F3: SBOP APPLIED FIRE PROTECTION}

\section{NEW PIRE PROTECTION MATERIALS SUITABLE FOR SBOP APPLICATION TO STEEL MEMBERS SBOULD BE DEVELOPED.}

Field application of fire protective coatings for steel structures is costly. Material and application cost can amount to as much as 15 of the cost of the steel frame. Existing materials cannot withstand the rigors of transportation and erection and are not suitable for shop application. Ablative coatings which could be applied in the shop are prohibitively expensive.

Background information should be collected to stimulate materials manufacturers to develop new coatings. This information would include a definition of the size of the potential market for such materials and the characteristics required to insure adequate performance during shop application, transportation, erection and subsequent fire conditions.

A two man-year level of effort is required. 


\section{RECOMMENDATION F4: LARGE AREA/LARGE VOLOME STRUCTURES}

\section{MATHEMATICAL MODELS SHOULD BE DEVELOPED FOR MODELING FIRE GROWTH IN LARGE AREA OR IAARGE VOLOME STRUCTURES.}

During the past two decades, a considerable amount of research has been done on the modeling of fully developed compartment fires. Much of this work is empirical and is based on experiments involving relatively small compartments. There are many large area/large volume structures which are commercially important to the steel industry. Examples include atriums, covered shopping malls, transportation terminals, covered stadiums and sports complex's and indusrial plants. It is questionable whether currently available models are applicable to such structures.

Fire models should be developed for large area/large volume structures taking into account the following factors: ventilation, plume theory, relatively low fire loading, heat dissipation, and the probability of occurrence of fully developed fire conditions (flash over).

A three man-year level of effort is required.

\section{RBCOHMENDATION F5: FIRE RESEARCH REVIEW}

\section{A COMPIIATION AND ASSESSMENT OF PIRE RESEARCH AROUND THE WORID SHOULD BE PREPARED ON A PBRIODIC BASIS.}

There is a great deal of fire research being conducted throughout the world. It is important that this work be sumarized to minimize duplication of effort and enhance the opportunity for synergism. The summary should deal with all aspects of fire research of importance to building design. It should be updated on a periodic basis, perhaps every 3-5 years.

A one man-year level of effort is required.

\section{G. DESIGN LOADS}

Loading characteristics such as load magnitude, duration and probability of occurence are important elements of design criteria for producing safe, economic structures. Research is needed to characterize snow loads, wind loads and crane loads. Information is also needed on the response of structures and structural elements to these loads. 


\section{RECOMMENDATION GI: CRANE LOADS \\ DESIGN LOADS SHOULD BE DETERMINED FOR OVERHEAD AND ONDERHUNG CRANE SYSTEMS.}

There is a lack of information available on the lateral forces developed by crane systems in industrial buildings.

Research involving field investigations should be conducted to determine the magnitude of these loads. Information should be obtained on the probability of occurence of various load combinations. Using this information, analytical and experimental studies should be carried out to establish fatigue requirements, serviceability and strength design criteria. Design requirements should also be established.

A three man-year level of effort is required.

\section{RECOMMENDATION G2: DRIFTED SNOW \\ DESIGN LOAD DATA SHOULD BE DEVELOPED FOR DRIFTED SNOW ON MULTI-LEVEL ROOFS.}

Drift snow loads account for about 75 percent of snow related roof collapses. The problem is particularly important for low rise steel buildings with a change in roof elevation such as industrial or manufacturing buildings with attached offices, school buildings, etc.

Needed research includes snow load measurements from fullscale structures and statistical analysis of drift snow load case histories to determine the effects of geometrical and environmental parameters and establish annual probabilities of exceedance.

A one man-year level of effort is required for a two to three year period.

RECONMENDATION G3: CLADDING BEHAVIOR

RATIONAL DESIGN PROCEDURES POR CLADDING SHOULD

BE DEVELOPED TARING INTO ACCOUNT THE

CBARACTERISTICS OF FLUCTUATING WIND PRESSURES,

CLADDING MATERIALS AND CONSTRUCTION PRACTICES.

Pressure coefficients contained in current loading standards and building codes reflect improvements in wind tunnel modeling of buildings. The techniques and instrumentation used to measure surface pressures on wind tunnel models have not been 
standardized. However, data obtained in full-scale and model scale tests suggest that peak pressure coefficients based on localized fluctuations may be underestimated in the wind tunnel by 15 to 25 percent. Certain phenomena associated with flow separation are not observed on wind tunnel pressure models because of instrumentation limitations.

Research should be conducted to validate wind tunnel modeling techniques (including the associated instrumentation) through carefully conducted measurement programs in both model and full-scale. The behavior of cladding elements subjected to fluctuating loads needs to be investigated systematically. Special laboratory equipment capable of duplicating actual load time histories obtained from field measurements will be needed. This information should be synthesized and rational design procedures should be developed that account for fluctuating pressures, cladding geometry and type of material, and fastener details.

A three man-year level of effort is required for the fullscale measurements and a five man-year level of effort for the behavior of cladding materials and development of design proceảures.

\section{RECOHMENDATION G4: WIND LOADS ON LOW RISE BUILDINGS}

\section{THE VARIABILITY OF WIND LOADING ON LOW RISE} BUILDINGS SHOULD BE BETTER DEF INED.

Additional information is needed on the effects of geometric and environmental factors on the variability of wind loads for low rise buildings.

The required research includes a synthesis of information available in the literature and wind tunnel studies.

A two to three man-year level of effort is required.

\section{RECOHMENDATION G5: INTERNAL PRESSURE LOADING \\ MODELS FOR MEAN AND PEAR INTERNAL PRESSURES \\ ASSOCIATED WITH WIND LOADS ON BUILDINGS SHOULD \\ BE VBRIFIED.}

Internal pressures affect the design of cladding on low rise buildings and curtain wall systems in high rise buildings. Current analytical models for the mean and peak internal pressures are based on assumptions of the leakage distribution of the building envelope, the presence of large openings in the exterior, the distribution of interior leakage paths (doors, walls, etc.) and the building flexibility. 
Experiments at both model scale and full-scale should be conducted to evaluate these models and develop improved design criteria.

A three man-year level of effort is required.

\section{RECOHMNDATION G6: BUILDING RESPONSE TO WINDS}

MEASURBMENTS SHOULD BE MADE OF THE RESPONSB OP FULL-SCALE STRUCTURBS SUBJECTED TO WIND LOADS.

Serviceability requirements and building performance as perceived by the occupants for high rise buildings subject to wind loads are important design considerations. Additional information on the dynamic performance of full-scale structures is needed to develop improved design criteria.

Research should be conducted on full-scale high rise structures subjected to wind loads to obtain information on the following: effective structural damping (nominal values available to the designer give concrete buildings an advantage), evaluation of building periods and comparison with calculated values, building drift and rotation, and building accelerations. The work should be carried out in hurricane prone areas where there is a high probability of experiencing strong winds.

A three man-year level of effort is required.

\section{RECOMENDATION G7: LARGE AREA ROOFS \\ MEASUREMENTS SHOULD BE MADE ON THE DISTRIBUTION OP SNON IN THE PRESENCE OF STRONG WINDS ON ROOFS OF LARGE AREA.}

Snow loads for roofs of low rise industrial, commercial or public buildings where the roof system represents a major portion of the construction cost are an important design consideration. Current research in the United States and Canada includes fullscale monitoring programs, probabilistic modeling of the formation and statistical variability of snow loads and physical model studies. The presence of strong winds, however, can cause significant non-uniform deposition and drifting.

Snow load monitoring programs should be conducted on fullscale structures, with emphasis on roofs of large area or unusual shape, to obtain information on the joint occurrence of extreme snow and wind loads, snow load distributions, and the duration of design snow loads. The program should include re-examination of existing data to develop correlations with climatic information, development of improved physical modeling techniques for wind tunnels and/or water flumes, and evaluation of existing 
mathematical models.

A three man-year level of effort is required. 


\section{ACKNOWLEDGMENTS}

The success of the workshop was due to the enthusiastic participation of all the attendees.

The workshop steering Committee played a key role in defining the research areas for the individual working groups and selecting the participants. The workshop was sponsored and jointly funded by the American Institute of Steel Construction, the American Iron and steel Institute, the Metal Building Manufacturers Association, the National Science Foundation and the National Bureau of Standards. Funding for participation of the university researchers was provided by the National Science Foundation through the efforts of $\mathrm{Dr}$. John Scalzi.

Several participants, who were unable to attend the workshop, contributed problem statements for the working groups to consider. We appreciate the contributions received from Theodore Galambos, Hal Iyengar, Arthur Arndt, and Harry Weese.

John Gross assisted in preparing the report and Bruce Ellingwood reviewed the final draft.

Mrs. Wanda Eader from the National Bureau of Standards provided administrative support in planning and conducting the workshop and typing the proceedings. 
APPENDIX A

\title{
WORRSHOP REYNOTE SESSION
}

\author{
Remarks \\ by \\ Dr. Ernest Ambler \\ Director, National Bureau of Standards
}

I appreciate the opportunity to appear before you today to welcome you to the National Bureau of Standards. NBS is pleased to sponsor this workshop along with the National science Foundation, the American Institute of Steel Construction, the American Iron and Steel Institute, and the Metal Building Manufacturers Association.

This workshop has been convened to develop consensus recommendations for steel building research, and to establish priorities for consideration by industry and government. In these two days you will begin to establish the basis for a collaborative relationship among federal agencies, university researchers, design professionals, and the U.S. steel industry.

Here at the National Bureau of Standards we are very proud of our participation in many strong and productive cooperative research efforts with industry, universities, and other federal agencies. We are all working together to assure the continued growth and strengthening of our economy, especially through the application of science and technology to our industries. Our research programs at NBS are enriched by the type of cooperation and collaboration in which you are expressing an interest by your presence here today.

I would like to give you some background on the rather long history of cooperation between NBS and the steel industry. For more than 80 years, NBS has been working with the steel industry to improve the durability and performance of metals and alloys. Starting in 1903, NBS began work to determine the melting points of pure metals as part of our mission to perform basic measurements. In 1912, because of an alarming number of railroad accidents, Congress appropriated special funds for NBS to conduct materials investigations on railroad iron and steel. By 1913, our Metallurgy Division had been formed. In 1919, NBS provided the first explanation of the phenomenon of age hardening of metals. By 1930, through improved technology, better steels were being used for rails and cars and the railroad accident rate fell by $2 / 3$, from a high of 36,000 accidents in 1920 .

World War II brought national concern for conservation of strategic raw materials such as chromium, tungsten, and 
molybdenum used in steel manufacturing. NBS investigated "lean alloy" steels and developed new coatings and processes to help meet these concerns.

Since the post-war years, NBS has been actively pursuing our present mission. We provide industry, government agencies, and scientific organizations with data, measurement methods, standard reference materials, concepts, and information on the fundamental aspects of processing, structure, physical properties, and performance of metals and alloys.

Currently there are quite a few NBS programs supportive of the U.S. steel industry. For example: Steel producers use our Standard Reference Materials (SRM's) to provide quality assurance for their materials. These samples have specific chemical or physical properties certified by the Bureau. They are used in calibrating instruments, checking chemical composition, and controlling production of various steels. Today, approximately 30 percent of the 40,000 SRM's sold annually are to producers and users of steel and metal alloys.

NBS is working with the American Iron and steel Institute (AISI) to develop process control sensors for rapid measurement of temperature distributions and automatic detection of porosity during manufacture. Also with AISI we are working to develop diagrams that will help designers select A36 structural steel products for load-bearing capacity and other performance characteristics related to fire safety.

The American Society for Metals (ASM) has raised $\$ 4$ million to cover its participation in a collaborative effort in which NBS is providing technical guidance on alloy phase diagrams. In 1982 the National Association of Corrosion Engineers (NACE) and NBS established a cooperative corrosion data program to help reduce corrosion damage to the nation's infrastructure -- its bridges, buildings, industrial plants, vehicles, and utilities.

In our welding research program, NBS scientists are working side-by-side with researchers sponsored by the Welding Research Council (WRC) and the American Welding Institute (AWI), formerly known as the American Welding Technology Application Center (AWTAC). NBS welding research is developing the scientific bas is to control the formation of flaws during welding, to nondestructively inspect welds to measure flaw size, and to develop models to predict the effect of weld flaws on structural integrity. Most of those examples are collaborations involving the NBS Center for Materials Research.

In the Center for Building Technology (CBT) our research has supported the development by the American Institute of Steel Construction (AISC) of load and resistance factor design for steel structures. CBT is currently working with AISC on a project to determine the performance of connections in steel braced frames. We have good reason to be proud of our support for the steel industry. We are delighted now to have the 
opportunity to focus more attention on structural engineering. We are particularly excited about this new focus because of the current interest in testing large scale structural components and systems.

This afternoon you are scheduled to visit our 12-million pound capacity Large Scale Structural Research Facility and the 3-Dimensional structural Testing Facility. The Large Scale Structural Research Facility will be used later this year to test the performance of full-scale bridge and building components subjected to earthquake loads. NBS research facilities are available for cooperative work with industry and, under certain conditions, facilities are even available for proprietary research.

In closing, I would like to state that we look forward to continued cooperation with the steel industry. I trust you will have a productive workshop and that you will enjoy your meeting here at NBS. 


\section{Remarks}

\section{by \\ Dr. John McTague \\ Deputy Director, Office of Science and Technology Policy}

Thank you for the opportunity to get outside the Beltway for a brief period. It's nice to see real scientists and engineers again. Even the air is different--there's no odor of fire and brimstone coming from our neighbors in the Executive office Building!

This workshop involving industry, government, and university participants to discuss research needs for steel buildings comes at a highly symbolic time. Just over a month ago, the President's Commission on Industrial Competitiveness reported to the President on ways to improve the U.S. position in an increasingly international and increasingly competitive world market. These eminent individuals--corporate CEO's, bankers, labor leaders, lawyers, and government officials--deliberated for some eighteen months. They identified eight major factors which affect this, or any other, Nation's ability to compete.

They were items such as the cost of labor, the cost of capital, exchange rates, trade policies, etc. They then rated these as advantageous, neutral, or disadvantageous for the U.S. competitive position. The cost of labor is obviously disadvantageous for the U.S. competitive position, and we wouldn't have it any other way--we want American workers to be the most prosperous in the world. None of the others I enumerated possess potential advantage for us, either. The only advantages we have lie in technology and talent. To quote from the report:

\footnotetext{
".... America owes much of its standard of living to U.S. preeminence in technology. In order to make technology a continuing competitive advantage for the United States, we need to do three basic things: (1) create a solid foundation of science and technology that is relevant to commercial uses; (2) apply advances in knowledge to commercial products and processes; and (3) protect intellectual property..."
}

So here you are today, one step ahead of the President's Commission. You are already using the combined strengths of the three sectors to cooperate to the advantage of all. If you are successful in handling cooperative government-industry-university research to advance the art in your field, and if your efforts are repeated in other fields, we as a Nation can be confident of success in this global competion. 
It is also particularly fitting that you should convene at the National Bureau of Standards, which has such a long and successful track record in cooperative ventures to strengthen our technology base. As the slogan of a former employer of mine goes, this is "Where Science Gets Down to Business."

Best wishes for a stimulating and successful workshop. 


\section{Remarks}

\section{by \\ John H. Busch \\ Chairman \\ American Institute of Steel Construction}

Thank you for inviting me to be with you today. It is my pleasure to welcome you on behalf of a very important segment of the steel construction industry, the American Institute of steel Construction. Most of you are familiar with AISC, what it does, and where it has been. This morning I would like to use my time to tell you about some of the things AISC is doing, where we could be headed, and offer a few challenges.

First, a little background information. AISC is the trade group that represents the fabricated structural steel industry with over 430 active member firms in the United states. AISC member firms are involved in the fabrication of diverse structures for a wide range of building and non-building construction applications. The most prominent of these are custom designed steel framed buildings and steel bridges. Throughout its 63 year history, AISC has been highly engineering oriented with a strong emphasis on steel research and steel design techniques. It has published many technical publications including the "bible" of the industry - the AISC Manual of steel Construction - which contains the well known AISC Code of Standard Practice and the AISC Specifications for the Design, Fabrication and Erection of Structural steel for Buildings. These documents are the basis for most steel building contracts and designs in this country as well as other parts of the world.

Currently the fabricated structural steel industry is shipping over 4.5 million tons annually worth over 5 billion dollars. This is down from nearly $7.0 \mathrm{million}$ tons and 8 billion dollars four years ago. This industry has been in a free fall and the slide has not ended for many. Building steel represents approximately $65 \%$ of the total tonnage shipped for our standard industrial classification No. 3441 .

AISC operates on a budget of nearly $\$ 4.0 \mathrm{million}$ annually with a staff of over 55 people including its highly prized 20 regional engineers located in key cities throughout the United states. In a word, AISC is a "technical" organization.

A few years ago, AISC Headquarters were moved from New York to Chicago. A change, and as part of that change, AISC decided to market its technical expertise. That marketing effort, based on statistical data and backed by hard core engineering and research studies, is gradually reaping benefits. This, despite the overall decline in the capital sector of the economy and its negative impact on the fabricated structural steel industry. Our objective is to gain a bigger share of a shrinking pie for the 
fabricated structural steel industry.

To organize for this goal a long range strategic planning task group was formed over a year ago. Detailed studies are being developed, and the current schedule calls for this strategic plan to be presented to the industry by December of this year. The plan will incorporate five key objectives:

- Market Share Penetration

- Technology

- Membership Enlargement and Involvement

- Government Relations

- Public Image

As you may note, technology is a vital factor in this planning.

The American Association of Engineering Societies in a recent paper points out that the united states is faltering in the area of research and development and concludes that the activities which move new technology from research to defined commercial potential are inadequate. This group goes on to report the strong correlation between research and improved productivity in manufacturing. Economist Edward F. Denison rates the various contributions to productivity as follows:

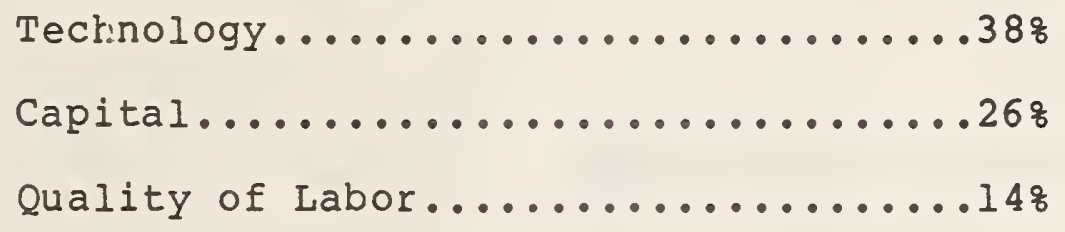

Economies of Scale..................

Resource Allocation................10\%

Again, technology is the largest single factor to secure strength for our industry in the market place through productivity improvements. Some of the technological areas that have been identified for progress include:

- Computer - Aided Engineering

- Flexible Manufacturing Systems

- Office Operations

- Advanced Manufacturing Methods

- Advanced Software Systems 
- Computers

- Materials Technology

- Energy

The American Association of Engineering Societies asks the key question: Who is going to do these studies? They point out that these long term programs require patience, organized and steady administration along with continuous funding. They further suggest that new imaginative cooperative arrangements deriving support from many sources, deserve urgent consideration. In Japan and Germany, institutes from many industries not only work closely with the academic experts but have substantial government support as well. We need to look closer at these possibilities in the United States.

As a mature industry, we cannot compete dollar for dollar with the high growth sectors of the economy in our research efforts. But we can compete with them conceptually in our research direction. Let's look at a leading technical company for comparative purposes. United Technologies is a 16 billion dollar company with an after tax return on equity of over 16 percent. Its growth rate for the past five years averages about 8 percent per year (despite a major downturn in 1982). United Technologies employs over 200,000 people and includes the following companies in its conglomerate portfolio:

Carrier Air Conditioning

Otis Elevator

Essex

Building Systems Company

Pratt \& Whitney

Elliott

Sikorsky

Norden, Inmont

Mostek and others

In their 1984 annual report, United Technologies states,

"High technology is the common denominator of all we do. Through the successful management of technology we are able to grow and to contribute to the world economy. Few corporations spend as much as we do on research and development. Our long standing policy is to invest wisely substantial amounts of company funds in 
advanced technology to yield superior products at the lowest possible cost."

Conceptually, despite the flair for high technology, their goals of superior products at the lowest possible cost should not be that much different from ours. This appears to match my earlier remarks about having an improved position in the market through innovative technology.

So, as you meet here today and tomorrow, the challenge is not only to involve your detailed and specific thoughts, but also to encourage creative new thinking. Traditionally, the research done in our industry has been more market reactive than that of anticipating the markets needs. AISC needs to provide you with more help in this area so that our research dollars can be spent in the direction that meets the needs of the market to secure the best results. I encourage you to consider these facts during your deliberations. From a fabricator's viewpoint, there are many factors that affect cost, but five major variables need to be collectively optimized to find the lowest cost. They are:

\section{Engineering Labor \\ Drafting Labor \\ Shop Labor \\ Erection Labor \\ Raw Material Cost}

Many steel designers correlate total cost savings with the reduced weight of the structure as it relates to raw material cost only and totally neglect the other variables. How many researchers are guilty of the same process? In other words, we need to be practical and consider all the factors that will affect our products and services in the reality of the market place. I feel confident that this workshop can be an important step in that direction. Thank you. 


\section{Remarks}

\section{by \\ Robert B. Peabody \\ President, American Iron and Steel Institute}

On behalf of the American Iron and steel Institute, I want to extend to all of you a warm welcome to this workshop on steel Research Needs for Buildings. We at AISI are genuinely pleased to be one of the sponsors and to join with the American Institute of Steel Construction, the Metal Building Manufacturers Association, the National Science Foundation, and the National Bureau of standards in an effort to identify realistic programs that will advance the state-of-the-art and improve safety and economy in building design, fabrication and construction.

Building construction is a large market for steel. We estimate some $4 \mathrm{million}$ tons of steel are consumed each year in buildings of all types. You can understand, then, the importance we place on this workshop.

This morning I would like to spend a few minutes to tell you something about AISI - who we are, what we do. Then I would like to comment on AISI structural research over the years and the impact of this research on building construction. Finally, I hope to leave you with some thoughts that you may wish to consider during your deliberations over the next two days.

Who are we? AISI is an association of steel producing companies. It is truly "American" in that its membership includes companies from North, Central and South America who account for $90 \%$ of the raw steel production in the western Hemisphere.

Our activities embrace research and technology to improve the steel manufacturing process, the collection and dissemination of statistics, public affairs, international trade and industrial relations including health, safety and hygiene. In addition, the Institute maintains field offices in cities throughout the United states, staffed by engineers who are responsible for industry activities related to building codes and regulatory standards that effect the use of steel mill products in construction.

A key part of our code work has been the Institute's continuing studies of fire hazards and fire protection. The object here is greater fire safety at lower building costs. In fact, I see that one of your workshop sessions is dedicated to the subject of needed fire research for buildings. We consider this to be an area where real economies can be effected.

The Institute also engages in promotional activities of general interest to the steel industry. These include publicity, 
booklets, trade show participation, motion pictures, seminars and educational programs. In addition, special promotion programs are carried out by individual product promotion committees whose company members produce a particular steel mill product - hot rolled and cold finished bars, sheet and strip, large diameter ine pipe, steel plate, structural steel and wire rope, to name a few.

With this brief description, you can see that AISI is a multifaceted organization engaged in all aspects that effect the steel industry.

This, then, briefly, is who we are.

Now let's be specific and turn our attention to AISI's structural research. This, after all, is why we are here. AISI's research in the structural area began in earnest about 20 years ago and it has embraced a number of topics included in this workshop - connections and members, frames, seismic design, and load and resistance factor design. Throughout this period, the main objective has been to increase the economy and safety of steel construction by (1) developing new structural concepts, (2) improving and updating the provisions of various design specifications and (3) preparing design guidelines and recommendations for use by the engineer.

The eccentrically braced frame is an example of a new structural concept developed through AISI research. The load and resistance factor design specification, another AISI project, will give engineers a rational guide for building design.

I should note here our cooperative research programs with government agencies, notably the Federal Highway Administration and the National Science Foundation. We have a joint program now underway with the Federal Highway Administration to test a onehalf scale model of a prototype bridge designed using innovative structural concepts. The model is to be tested sometime this year at the FHWA Turner-Fairbank Research Center, McLean, Virginia. Also, over the years, we have collaborated in projects of the National science Foundation relating to the design of earthquake-resistant structures.

These joint efforts with the government have been an important part of our research program.

In closing, I would like to leave you with a few thoughts. In the past, the steel producing and fabricating industries have been a major source of funding for structural related research. At one time these industries were able to freely support most proposals that were submitted for consideration by various research agencies. But, as you know, recent severe economjc pressures have eroded the funds that were once available. Obviously, we must now evaluate and prioritize projects on a more precise basis. Economy and safety now become essential factors when considering a research topic for funding. In fact, the 
words "economy" and "safety" are used in the stated objective of this workshop. I would urge you to keep these words in mind during your discussions within each working session. Please remember that the research priorities you set during the next two days will become important guidelines upon which the steel industry will base its future building research program.

The industry sincerely thanks you for the valuable time you are spending in its behalf and wishes you success in the arduous task to which you have committed yourself. I know the results of your work will provide benefits for all. Thank you. 


\section{APPENDIX B}

STEEL RESEARCH NEEDS FOR BUILDINGS

Program

\section{TUESDAY, MARCH 5,1985}

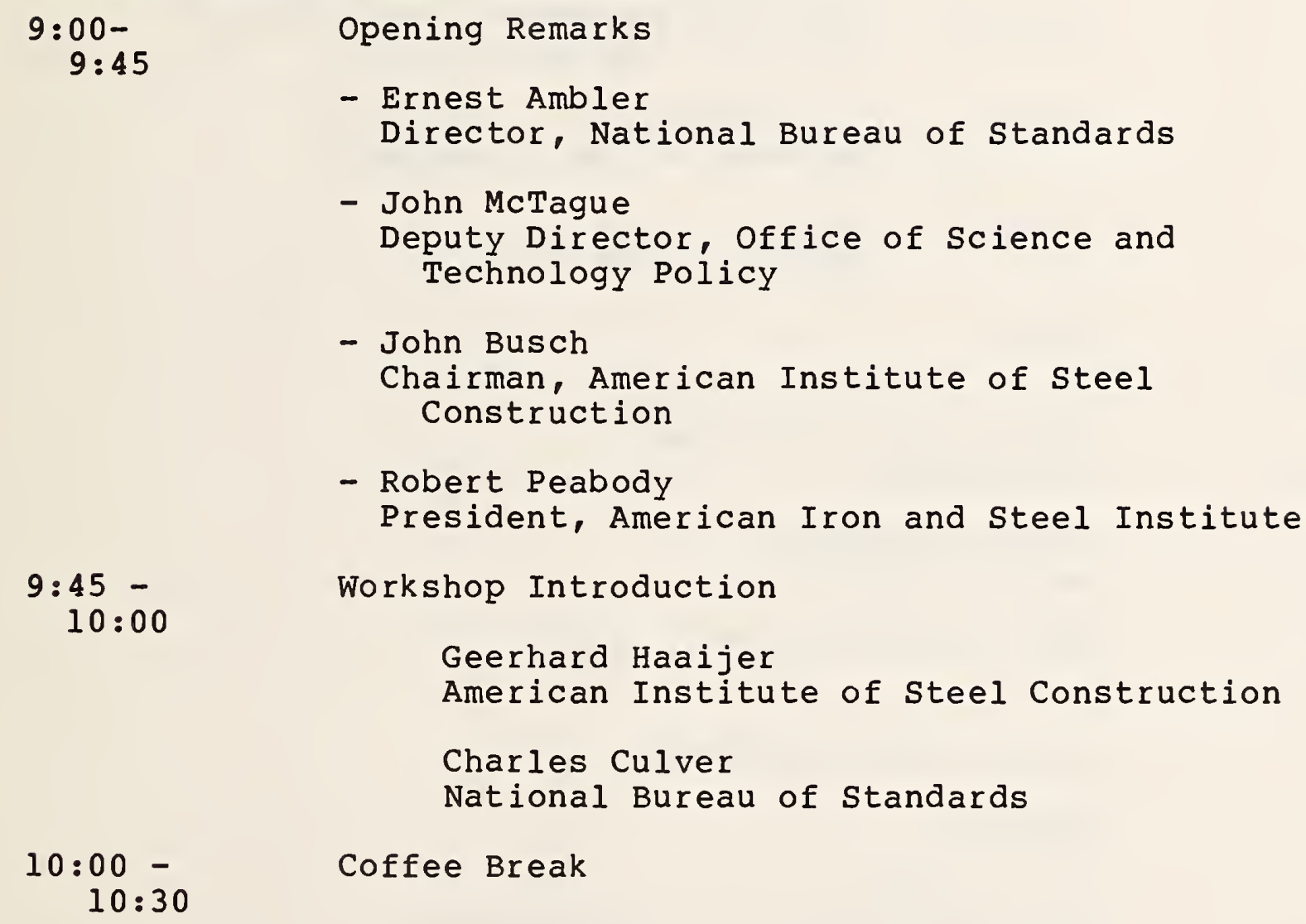

$9: 00-$

$9: 45$

Opening Remarks

- Ernest Ambler

Director, National Bureau of Standards

- John McTague

Deputy Director, Office of Science and Technology Policy

- John Busch

Chairman, American Institute of Steel Construction

- Robert Peabody

President, American Iron and Steel Institute

$9: 45-$

$10: 00$

Workshop Introduction

Geerhard Haaijer

American Institute of Steel Construction

Charles Culver

National Bureau of Standards
$10: 00-$
$10: 30$
$10: 00-$
$10: 30$
Coffee Break 


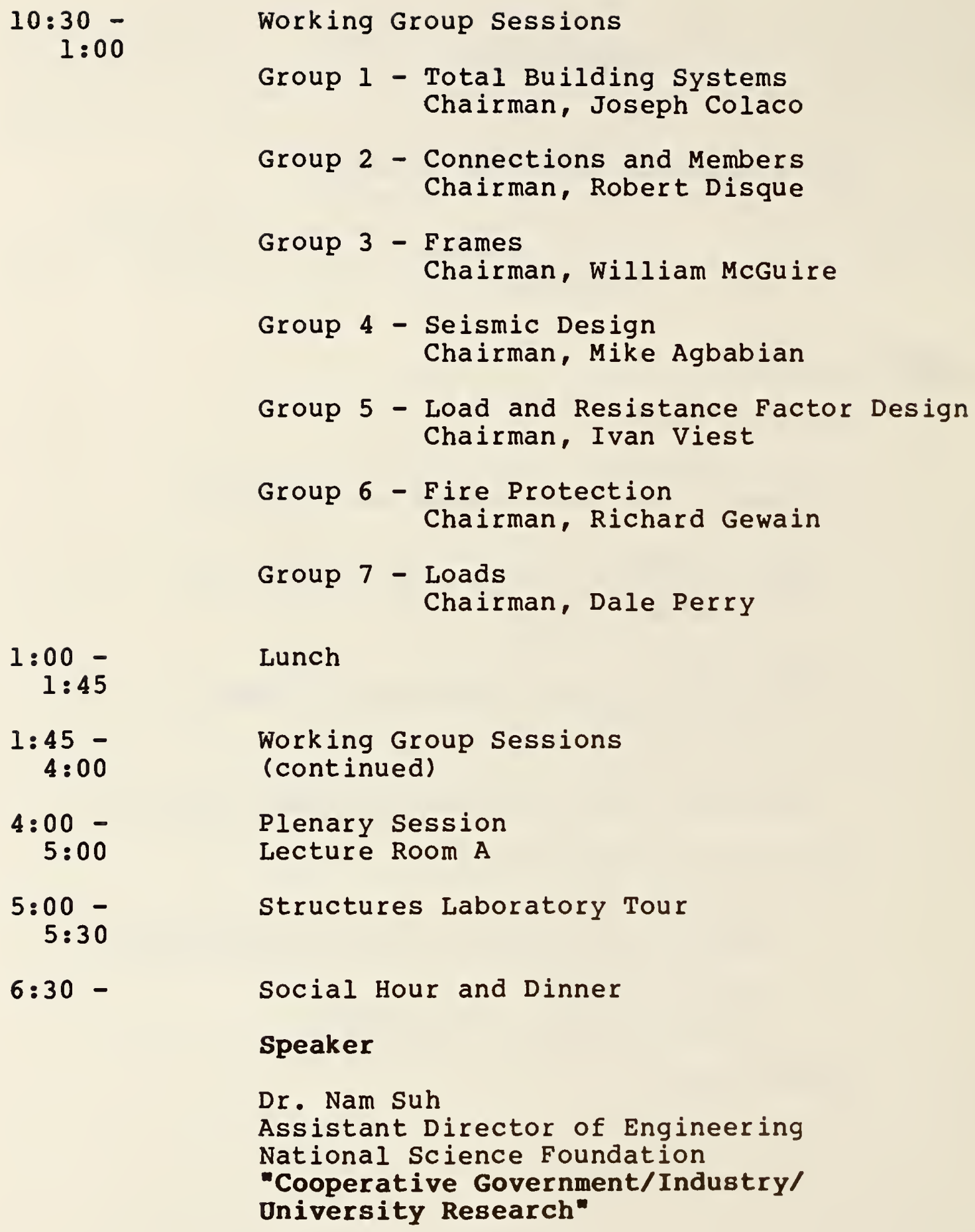




\section{MEDNESDAY, MARCH 6}

$\begin{array}{ll}9: 00- & \begin{array}{l}\text { Working Group Sessions } \\ \text { (continued) }\end{array} \\ 1: 00 & \text { Lunch } \\ 1: 45 & \text { Plenary Session } \\ 1: 45- & \begin{array}{l}\text { Lecture Room A } \\ 4: 00\end{array} \\ & \text { Develop final recommendations } \\ 4: 00- & \text { Closing Remarks } \\ 4: 15- & \text { Adjourn }\end{array}$




\section{LOCATION:}

National Bureau of Standards

Gaithersburg, Maryland

SPONSORED BY:

National Bureau of Standards

National Science Foundation

American Institute of Steel Construction

American Iron and steel Institute

Metal Building Manufacturers Association

\section{OBJECTIVE:}

To develop consensus recommendations for steel building research and establish priorities for industry and government consideration.

\section{PARTICIPANTS :}

Invited representatives from the steel industry, design professionals, Federal agency representatives and university researchers.

\section{STEERING COMMITTEE :}

Charles G. Culver, NBS (Chairman)

Joseph P. Colaco, CBM Engineers

Robert O. Disque, AISC

Richard Gewain, AISI

Geerhard Haaijer, AISC

Nestor R. Iwankiw, AISC

Albert C. Kuentz, AISI

William McGuire, Cornell University

Dale C. Perry, MBMA

Werner H. Quasebarth, Atlas Machine and Iron Works

Ivan M. Viest, Consulting Engineer 
APPBNDIX C

WORRSBOP PARTICIPANTS

\section{DESIGN PROEESSIONALS}

Mr. Horatio Allison

President

Allison, McCormac \& Nickolaus, P.A. 11810 Parklawn Drive

Rockville, Maryland 20852

Mr. Irwin G. Cantor

Office of Irwin G. Cantor

919 Third Avenue

New York, New York 10022

Dr. Joseph P. Colaco

President

CBM Engineers, Inc.

1700 west Loop South - Suite 830

Houston, Texas 77027-3092

Mr. Henry J. Degenkolb

H. J. Degenkolb Associates, Engineers

350 Sansome Street, Room 500

San Francisco, California 94104

Dr. James M. Fisher

Vice President

Computerized Structural Design, Inc.

5678 W. Brown Deer Road

Milwaukee, Wisconsin 53223

Mr. Jerome S.B. Iffland

President, Iffland Ravanagh Waterbury 1501 Broadway

New York, New York 10036

Mr. Socrates Ioannides

Senior Engineer

Stanley D. Lindsey \& Associates, Ltd. 1906 West End Avenue

Nashville, Tennessee 37203-2371

Dr. Stanley D. Lindsey

President

Stanley D. Lindsey \& Associates, Ltd. 1906 West End Avenue

Nashville, Tennessee 37203-2371 


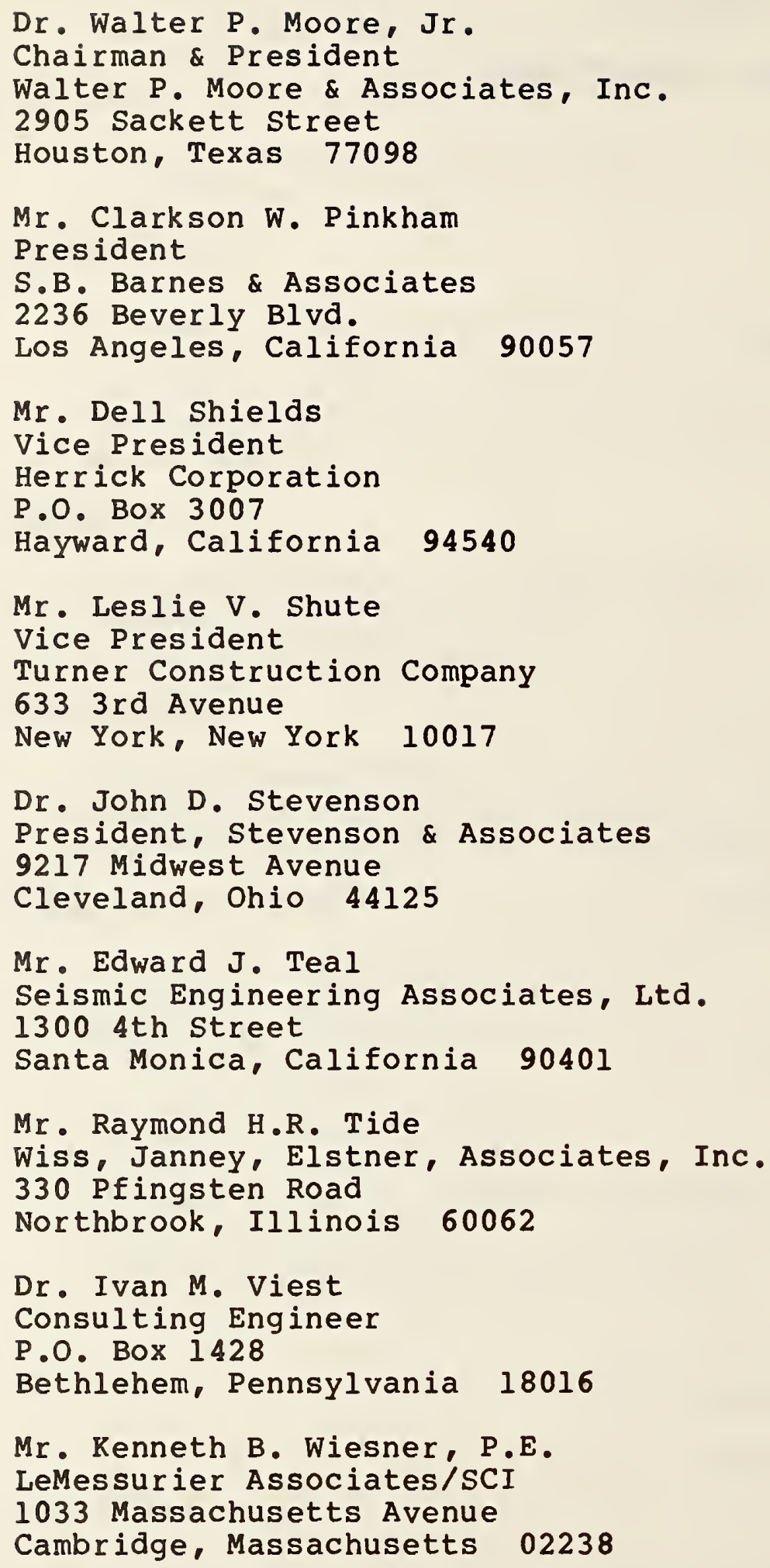




\section{INDOSTRY REPRESBNTATIVES}

Mr. Edward P. Becker, P.E.

Chief Engineer

Lehigh structural steel Company

Box 626

One Allen Street

Allentown, Pennsylvania 18015

Mr. Delbert F. Boring

Regional Director, Construction Codes \& Standards

American Iron and Steel Institute

4937 West Broad Street

Columbus, Ohio 43228

Mr. Roger L. Brockenbrough

Research Consultant

Heavy Products Division

U.S. Steel Corporation

Technical Center

One Tech Center Drive

Monroeville, Pennsylvania 15146

Mr. John H. Busch

President, Haven-Busch Company

3443 Chicago Drive, S.W.

Grandville, Michigan 49418

Mr. Andrew $\mathrm{R}$. Courtney

Chief Engineer

Owen Steel Company, Inc.

801 Blossom street

P.O. Box 1698

Columbia, South Carolina 29202

Mr. Robert O. Disque

Assistant Director of Engineering

American Institute of Steel Construction, Inc. The Wrigley Bldg.

400 North Michigan Avenue

Chicago, Illinois 60611-4185

Mr. William Y. Epling

Director of Government Affairs

American Institute of Steel Construction, Inc. Suite 400

$1629 \mathrm{~K}$ street, $\mathrm{NW}$

Washington, DC 20006 
Mr. Walter H. Fleischer

Senior Structural Consultant

Bethlehem Steel Corporation

255 SGO

Bethlehem, Pennsylvania 18016

Mr. Richard Gewain

Chief, Fire Protection Engineer

American Iron \& Steel Institute

1000 16th Street, NW

Washington, DC 20036

Mr. Michael Gilmor

Manager of Engineering

Canadian Institute of Steel Construction

201 Consumers Road

Suite 300

Willowdale, Ontario, M2J 4G8

Canada

Mr. John D. Griffiths

Vice President - Engineering

Paxton \& Vierling steel Co.

P.O. Box 1085

Omaha, Nebraska 68101

Mr. Joshua Gurman

American Iron and Steel Institute

1000 16th Street, NW

Washington, DC 20036

Dr. Geerhard Haaijer

Vice President

American Institute of Steel Construction

The Wrigley Bldg.

400 North Michigan Avenue

Chicago, Illinois 60611-4185

Mr. J. W. Hotchkies

Manager, Market Development Engineering

The Algoma Steel Corporation, Ltd.

Mississauga Executive Center, Suite 900

Four Robert Speck Parkway

Mississauga, Ontario

Canada L4Z 1SI 
Mr. Nestor Iwankiw

Assistant Director of Engineering

American Institute of steel Construction

The Wrigley Bldg.

400 North Michigan Avenue

Chicago, Illinois 60611-4185

Mr. Juris Jauntirans

3210 watlong street

Inland Steel Company

East Chicago, Indiana 46312

Mr. David C. Jeanes

American Iron and Steel Institute

1000 16th Street, NW

Washington, DC 20036

Mr. Donald L. Johnson

Senior Research Engineer

Butler Manufacturing Companny

Research Center

135th Street and Botts Road

Grandview, Missouri 64030

Mr. Larry Rloiber

Vice President

L. L. LeJeune Company

118 West 60 th Street

Minneapolis, Minnesota 55419

Mr. Henry V. Kominek

Regional Director

Construction Codes \& Standards

American Iron \& Steel Institute

1150 Wilmette Avenue

wilmette, Illinois 60091

Mr. Albert C. Kuentz

Staff Representative

American Iron \& Steel Institute

1000 16th Street, NW

Washington, DC 20036 
Mr. Hank Martin

Regional Director, Codes \& Standards

American Iron \& Steel Institute

671 Newcastle Road, Suite 1

Newcastle, California 95658-9702

Mr. Daniel M. McGee, P.E.

Regional Director, Construction Codes \& Standards

American Iron \& Steel Institute

P.O. Box $3 I I$

Matawan, New Jersey 07747

Mr. William E. Moore

Vice President - Engineering

Taurrier Street and Bredford

P.O. Box 753

Ferro Products Company

Charleston, West Virginia 25323

Mr. Heinz Pak

Engineering Consultant

United States Steel Corporation

600 Grant street

Pittsburgh, Pennsylvania 15230

Mr. Robert B. Peabody

President, American Iron \& Steel Institute

1000 16th street, NW

Washington, DC 20036

Dr. Dale C. Perry

Metal Building Manufacturers Association

Director of Engineering and Research

1230 Keith Building

Cleveland, Ohio 44115

Mr. Werner H. Quasebarth

President

Atlas Machine \& Iron Works, Inc.

7308 Wellington Road

Gainesville, Virginia 20065 
Mr. Bill Richey

Vice President Engineering

Havens Steel Company

7219 East 17 th Street

Kansas City, Missouri 64126-2890

Mr. Robert E. Roll

Manager of Structural Shapes \& Piling Marketing

Bethlehem Steel Corporation

Bethlehem, Pennsylvania 18016

Mr. Dell Shields

Vice President

Herrick Corporation

P.O. Box 3007

Hayward, California 94540

Mr. Gary F. Tilson

Regional Director, Codes \& Standards

American Iron \& Steel Institute

798 Rays Road, Suite 105A

Stone Mountain, Georgia 30083

Dr. William Thornton

Chief Engineer

Cives Steel Company

411 Rouse Lane

P.O. Box 768180

Atlanta, Georgia 30338

Ms. Lisa Vornholt

Regional Director

American Iron and Steel Institute

13500 Midway Road, Suite 111

Dallas, Texas 75234

Mr. Walter G. Wells

American Iron and Steel Institute

1000 16th Street, NW

Washington, DC 20036

Mr. R. T. Willson

American Iron and Steel Institute 1000 16th Street, NW

Washington, DC 20036

Mr. James Wooten

Chief, Structural Design Engineer

AFCO Steel

P.O. Box 231

1423 East Sixth Street

Little Rock, Arkansas 72201 


\section{UNIVERSITY RESEARCHERS}

Dr. Joel I. Abrams

Chairman, Department of Civil Engineering University of Pittsburgh

949 Benedum Hall

Pittsburgh, Pennsylvania 15261

Professor Mihran S. Agbabian

Chairman, Department of Civil Engineering University of Southern California

Los Angeles, California 90089

Dr. Wai Fah Chen

Professor \& Head, Structural Engineering

School of Civil Engineering

Civil Engineering Building

Purdue University

West Lafayette, Indiana 47907

Professor John W. Fisher

Fritz Engineering Laboratory

Building 13

Lehigh University

Bethlehem, Pennsylvania 18015

Professor Kurt H. Gerstle

Department of Civil Environmental and

Architectural Engineering

University of Colorado

Campus Box 428

Boulder, Colorado 80309

Dr. Robert D. Hanson

Professor of Civil Engineering

University of Michigan

Department of Civil Engineering

304 West Engineering Bldg.

Ann Arbor, Michigan 48109-1092

Professor Helmut Krawinkler

Department of Civil Engineering

Stanford University

Stanford, California 94305 
Professor Le-wu Lu

Civil Engineering Department

Fritz Engineering Laboratory

Lehigh University

Bethlehem, Pennsylvania 18015

Professor William McGuire

Cornell University

School of Civil and Environmental Engineering

Hollister Hall

Ithaca, New York 14853

Professor Thomas M. Murray

University of Oklahoma

School of Civil Engineering

202 W. Boyd Street, Room 334

Norman, Oklahoma 73019

Dr. Michael J. O'Rourke

Associate Professor, Civil Engineering

Rensselaer Polytechnic Institute

Troy, New York 12181

Professor Egor Popov

Professor Emeritus of Civil Engineering

University of California, Berkeley

College of Engineering

Berkeley, California 94720

Dr. James B. Radziminski

University of South Carolina

Department of Civil Engineering

College of Engineering

Columbia, South Carolina 29208

Dr. Charles W. Roeder

Department of Civil Engineering

University of Washington

233 More Hall, FX-10

Seattle, Washington 98195 
Dr. D. Surry

Boundary Layer Wind Tunnel Laboratory

Faculty of Engineering Science

London, Ontario

Canada N6A 5B9

Professor Joseph A. Yura

Warren Bellows Professor of Civil Engineering

University of Texas at Austin

Department of Civil Engineering

10100 Burnet Road

Austin, Texas 78758-4497 


\section{GOVERAMENT REPRESENTATIVES}

Mr. Gifford Albright

National Science Foundation

1800 G Street, NW

Washington, DC 20550

Dr. Hans Ashar

Research Manager

U.S. Nuclear Regulatory Commission

(NL 5650)

Washington, DC 20555

Dr. Charles G. Culver

Chief, Structures Division

National Bureau of Standards

Gaithersburg, Maryland 20899

Dr. Robert M. Dinnat

Associate Technical Director

Construction Engineering Research Laboratory

U.S. Army Corps of Engineers

Box 4005

Champaign, Illinois 61820

Dr. Bruce R. Ellingwood

Leader, Structural Engineering

Structures Division

National Bureau of Standards

Gaithersburg, Maryland 20899

Mr. Michael Gaus

National Science Foundation

1800 G Street, NW

Washington, DC 20550

Dr. John L. Gross

Research Engineer

Structures Division

National Bureau of Standards

Gaithersburg, Maryland 20899

Dr. H. S. Lew

Leader, Construction Safety

Structures Division

National Bureau of Standards

Gaithersburg, Maryland 20899

Dr. Edgar V. Leyendecker

Leader, Earthquake Hazards Reduction

Structures Division

National Bureau of Standards

Gaithersburg, Maryland 20899 


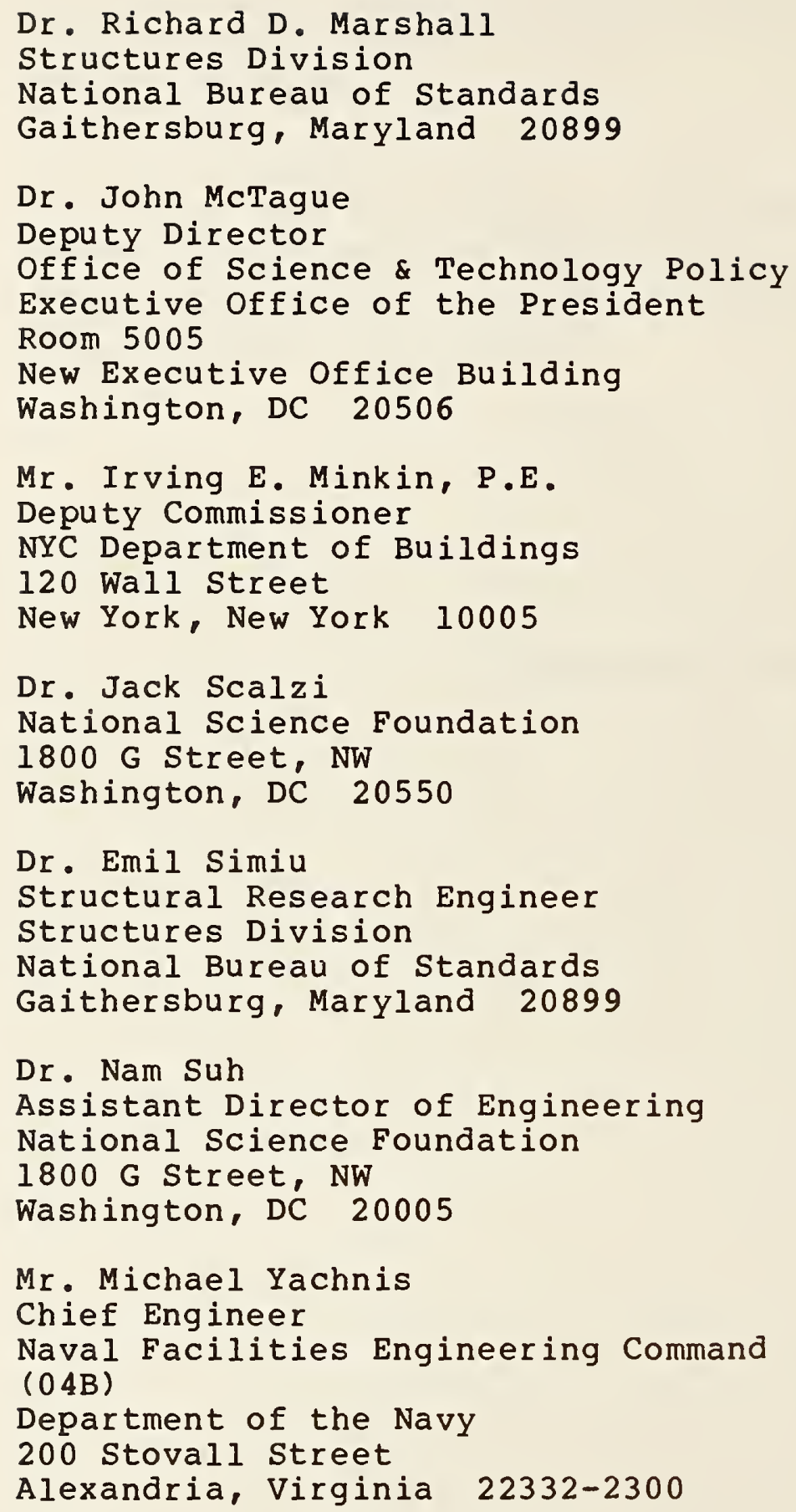


NBS-IIMA inEV. 200 )

U.2. OEPT: OF cONAM.

BIBLIOGRAPHIC DATA

1. PUBLICATION OR

REPORT NO.

2. Performing Orgen. Report Nod 3. Publication Date

SHEET (Soe inseructions)

May 1985

4. TITLE AND SUBTITLE

A Workshop on Steel Research Needs for Buildings

5. $\operatorname{AUTHOR}(\mathrm{S})$

Culver, C.G., Iwankiw, N., and Kuentz, A.

6. PERFORMING ORGANIZATION (If joint or other than NBS, see instructions)

7. ContractGrane No.

National Bureau of Standards

U.S. Department of Commerce

Gaithersburg, ID 20899

8. Type of Report \& Period Covered

Final

9. SPONSORING ORGANIZATION NANE ANO COMPLETE ADOKESS (Street, CItY, Stote, ZIF)

See title page

10. SUPPLEMENTARY NOTES

Document describes a computer program; SF-185. FIPS Software Summary, is attached.

11. ABSTRACT (A 200-word or less factual summary of most significant information. If document includes a significant bibliography or literoture survey, mention it here)

This report identifies needed experimental and analytical research to advance the state-of-the-art and improve safety and economy in the design, fabrication and construction of steel buildings. A five year plan for a coordinated research program is included. Recommendations for research projects dealing with the following topics are presented: Total building systems, connections and members, frames, seismic design, load and resistance factor design, fire protection, and design loads. The recommendations were developed at a workshop involving participation by steel industry representatives, design professionals, Federal agency representatives and university researchers.

12. KEY WORDS (Six to twelve entries: alphobetical order: copitolize only proper nomes: ond separote key words by semicolons)

Buildings; design; fire protection; loads; research; steel; structural engineering.

14. NO. OF PRINTED PAGES

89

15. Price 





\section{NBS Technical Publications}

\section{Periodical}

Journal of Research-The Journal of Research of the National Bureau of Standards reports NBS research and development in those disciplines of the physical and engineering sciences in which the Bureau is active. These include physics, chemistry, engineering, mathematics, and computer sciences. Papers cover a broad range of subjects, with major emphasis on measurement methodology and the basic technology underlying standardization. Also included from time to time are survey articles on topics closely related to the Bureau's technical and scientific programs. Issued six times a year.

\section{Nonperiodicals}

Monographs-Major contributions to the technical literature on various subjects related to the Bureau's scientific and technical activities.

Handbooks-Recommended codes of engineering and industrial practice (including safety codes) developed in cooperation with interested industries, professional organizations, and regulatory bodies.

Special Publications-Include proceedings of conferences sponsored by NBS, NBS annual reports, and other special publications appropriate to this grouping such as wall charts, pocket cards, and bibliographies.

Applied Mathematics Series-Mathematical tables, manuals, and studies of special interest to physicists, engineers, chemists, biologists, mathematicians, computer programmers, and others engaged in scientific and technical work.

National Standard Reference Data Series-Provides quantitative data on the physical and chemical properties of materials, compiled from the world's literature and critically evaluated. Developed under a worldwide program coordinated by NBS under the authority of the National Standard Data Act (Public Law 90-396).

NOTE: The Journal of Physical and Chemical Reference Data (JPCRD) is published quarterly for NBS by the American Chemical Society (ACS) and the American Institute of Physics (AIP). Subscriptions, reprints, and supplements are available from ACS, 1155 Sixteenth St., NW, Washington, DC 20056.

Building Science Series-Disseminates technical information developed at the Bureau on building materials, components, systems, and whole structures. The series presents research results, test methods, and performance criteria related to the structural and environmental functions and the durability and safety characteristics of building elements and systems.

Technical Notes-Studies or reports which are complete in themselves but restrictive in their treatment of a subject. Analogous to monographs but not so comprehensive in scope or definitive in treatment of the subject area. Often serve as a vehicle for final reports of work performed at NBS under the sponsorship of other government agencies.

Voluntary Product Standards-Developed under procedures published by the Department of Commerce in Part 10, Title 15, of the Code of Federal Regulations. The standards establish nationally recognized requirements for products, and provide all concerned interests with a basis for common understanding of the characteristics of the products. NBS administers this program as a supplement to the activities of the private sector standardizing organizations.

Consumer Information Series-Practical information, based on NBS research and experience, covering areas of interest to the consumer. Easily understandable language and illustrations provide useful background knowledge for shopping in today's technological marketplace.

Order the above NBS publications from: Superintendent of Documents, Government Printing Office, Washington, DC 20402.

Order the following NBS publications-FIPS and NBSIR's - from the National Technical Information Service, Springfield, VA 22161.

Federal Information Processing Standards Publications (FIPS PUB)--Publications in this series collectively constitute the Federal Information Processing Standards Register. The Register serves as the official source of information in the Federal Government regarding standards issued by NBS pursuant to the Federal Property and Administrative Services Act of 1949 as amended, Public Law 89-306 (79 Stat. 1127), and as implemented by Executive Order 11717 (38 FR 12315, dated May 11, 1973) and Part 6 of Title 15 CFR (Code of Federal Regulations).

NBS Interagency Reports (NBSIR)-A special series of interim or linal reports on work performed by NBSS for outside sponsors (both government and non-government). In general, initial distribution is handled by the sponsor; public distribution is by the National Technical Information Service, Springtield, VA 22161, in parer copy or microfiche form. 
U.S. Department of Commerce National Bureau of Standards Gaithersburg, MD 20899

Official Business

Penalty for Private Use $\$ 300$ 